\title{
Bear Factor and Hedge Fund Performance*
}

\author{
Thang $\mathrm{Ho}^{\dagger} \quad$ Anastasios Kagkadis ${ }^{\ddagger} \quad$ George Wang ${ }^{\S}$
}

This version: August 2021

\begin{abstract}
We show that a simple and intuitive variable, the return of a bear spread portfolio orthogonalized with respect to the market (H-Bear factor), can serve as a new benchmark for explaining the cross-section of hedge fund returns. Low H-Bear exposure funds (bear risk insurance sellers) outperform high H-Bear exposure funds (bear risk insurance buyers) by $0.58 \%$ per month on average, outperform even during market crashes, but underperform when bear market risk materializes. Overall, we identify a new risk dimension that affects hedge fund performance, and we show that this risk factor is distinct from the already popular realized tail risk.
\end{abstract}

JEL Classification: G11, G12, G23

Keywords: Hedge funds, Bear portfolio, H-Bear factor, Tail risk, Insurance.

${ }^{*}$ We are indebted to Vikas Agarwal, Charlie Cai, Spencer Martin, Andrew Sinclair (discussant), Chandra Sekhar Mangipudi (discussant), and participants at Queen's University Belfast, University of Liverpool, Lancaster University, the $14^{\text {th }}$ Conference on Asia-Pacific Financial Markets, the $33^{\text {rd }}$ Australasian Finance and Banking Conference, and the $2^{\text {nd }}$ Frontiers of Factor Investing Conference for helpful comments. An earlier version of this paper was circulated under the title "Bear Market Risk and the Cross-Section of Hedge Fund Returns".

‘Department of Accounting and Finance, Lancaster University Management School, Lancaster LA1 4YX, United Kingdom. Email: m.t.ho@lancaster.ac.uk.

Department of Accounting and Finance, Lancaster University Management School, Lancaster LA1 4YX, United Kingdom. Email: a.kagkadis@lancaster.ac.uk.

${ }^{\S}$ Department of Accounting and Finance, Lancaster University Management School, Lancaster LA1 4YX, United Kingdom. Email: george.wang@lancaster.ac.uk; Currently visiting faculty at the Finance Department, New York University Stern School of Business, Email: jwang@stern.nyu.edu 


\section{Introduction}

Building on Lu and Murray's (2019) insight, we document that a market hedged bear factor (H-Bear) can effectively explain a large proportion of the variation in the cross-section of hedge fund returns. ${ }^{1}$ The H-Bear factor carries a negative bear risk premium $(-1.09 \%$ per month, t-statistic $=-6.77)$ which compensates for the change in ex-ante probability of future bear market states on top of what is justified by concurrent market returns. ${ }^{2}$ The economic intuition behind the negative premium is that assets that pay off when there is an increasing probability or concern about future bear market states should earn lower average returns because they serve as hedging or insurance instruments. Along this line, hedge funds can be quantified as "insurance buyers" if they have positive exposure to the H-Bear factor and "insurance sellers" if they have negative exposure. ${ }^{3}$

We argue that hedge funds behave much like conventional assets in this economy, earning a premium for being exposed to the H-Bear factor and vice versa. Our empirical analysis provides strong support in favour of this argument. Specifically, we measure H-Bear exposure for each hedge fund in each month by regressing its excess returns on the H-Bear factor over a 24-month rolling window. Then we sort hedge funds based on their exposure to the H-Bear factor, i.e., H-Bear beta, group them into quintiles, and examine the average

${ }^{1}$ Lu and Murray (2019) highlight that bear market risk, as captured by the return of a bear spread portfolio hedged with respect to the market return, is priced in the stock market.

${ }^{2} \mathrm{H}-\mathrm{Bear}$ factor is constructed using S\&P 500 index options in the following way: We go long an out-of-themoney (OTM) put and short a further OTM put, so that the overall position pays off $\$ 1$ when the S\&P 500 index is 1.5 standard deviations below its forward price. The return of this portfolio is regressed against the market return and the residuals from this regression constitute the H-Bear factor. More details are provided in Section 2.2.

${ }^{3}$ Specifically, we posit that the trading activity of hedge funds through the usage of options, leverage, short sales, etc. leads to payoffs that are effectively close to an insurance buying or selling strategy (see also, Stulz, 2007; Agarwal and Naik, 2004; Ang, 2014; Gao, Gao, and Song, 2018). Hedge funds that act as insurance buyers are referred to as "black swan" funds in the financial press. 
returns of these quintiles over the next one month. Remarkably, hedge funds in the lowest H-Bear beta quintile ("insurance sellers") outperform those in the highest H-Bear beta quintile ("insurance buyers") by $0.58 \%$ per month (t-statistic $=3.53$ ) on average. The riskadjusted return spread between the high and low H-Bear beta quintiles remains significant based on the Fung and Hsieh (2004) seven-factor model as well as other performance evaluation models used in the asset pricing literature. The results also hold for valueweighted portfolios and the predictive power of H-Bear factor loading for future hedge fund returns extends as far as 18 months ahead. Moreover, a Fama-MacBeth (1973) regression analysis demonstrates that the H-Bear beta effect remains particularly robust when controlling for a large set of alternative hedge fund characteristics and exposures to various other risk factors. Overall, our analysis suggests that the H-Bear factor is arguably one of the strongest hedge fund return predictors that have appeared in the literature. ${ }^{4}$

In an influential and related study, Gao, Gao, and Song (2018) suggest that certain hedge funds possess skills in exploiting overpriced ex-ante market disaster risk concerns, and thus persistently outperform other hedge funds. By adopting an alternative measure of innovations in ex-ante bear market concerns, we offer a risk-based explanation of hedge fund returns. In our framework, the persistent spread between the hedge funds with low and high H-Bear exposure reflects the bear risk premium. And such spread does not require any skills in trading over-priced "fear premium" or that the bear insurance sellers possess superior market timing ability than the buyers. Our study, therefore, contributes a new and potentially important risk perspective in explaining hedge fund performance.

\footnotetext{
${ }^{4}$ There are a few potential reasons why the H-Bear factor could exhibit strong explanatory power for hedge fund returns. One is that hedge funds are known to trade bear-spread portfolios and other option portfolios or using complicated strategies with option-like payoffs (Agarwal and Naik, 2004; Aragon and Martin, 2010; Lu and Murray, 2019). Another reason is that the H-Bear factor provides an effective way to quantify hedge funds' hedged positions, while the previous literature is unable to do so because it mainly focuses on using unhedged call or put options to evaluate hedge fund performance.
} 
The H-Bear factor can be viewed as a measure of the change in ex-ante downside or tail risk orthogonalized to market returns, whereas most existing studies use ex-post measures based on realized losses conditional on market crashes (see, for example, Jiang and Kelly, 2012; Agarwal, Ruenzi, and Weigert, 2017). In other words, H-Bear factor captures a different and important dimension of tail risk. In a related study, Agarwal, Ruenzi, and Weigert (2017) show that hedge funds with high market tail risk outperform hedge funds with low tail risk on average but underperform in periods of negative market returns. Moreover, they find that tail risk arises naturally because several popular hedge fund trading strategies resemble writing out-of-the money put options on the equity market index. This has given rise to a conventional wisdom which suggests that certain hedge funds tend to act more as insurance sellers, collecting an insurance premium in good market periods (i.e., in most of the cases) and experiencing substantial losses in bad market periods (i.e., in a few cases). Our study naturally extends Agarwal, Ruenzi, and Weigert (2017) by providing a forward-looking perspective to quantify hedge funds as insurance sellers and buyers without conditioning on past or current market conditions.

We delve into the economic nature of the H-Bear factor's predictive ability, by first showing that the returns of the hedge funds who buy (sell) insurance can be seen as the outcome of a combination of unhedged market exposure and long (short) market-hedged insurance exposure. We further find that both insurance buyers and sellers have positive and almost identical unhedged market exposure. ${ }^{5}$ Hence, we conclude that the systematic

\footnotetext{
${ }^{5}$ This implies that hedge funds who seek insurance tend to have very high market exposure beforehand, but they only hedge part of their portfolio, leaving a significant part of their market exposure unhedged. The high initial market exposure of insurance buyers is also the reason why controlling for the market factor is necessary in our exercise. If we do not control for the market (i.e., if we use the Bear portfolio return rather than the H-Bear factor), the market exposure dominates the Bear portfolio exposure, the estimated beta becomes negative, and the insurance buyers are incorrectly regarded as sellers.
} 
difference in the expected returns of high versus low H-Bear beta funds arises as a natural outcome of their differential exposure to the market-hedged insurance returns.

Our study challenges the conventional wisdom which directly associates the returns of insurance-like hedge fund strategies with realized market returns. Such a link requires that the two have an (almost) perfect negative correlation. Following Lu and Murray (2019), we confirm that this correlation is far from perfect. In particular, it is possible that there is a high increase in investors' fears about future bear market states even if there is little or no negative market return. In this case, the gain (loss) for the insurance buyer (seller) is high. In the same vein, it is possible to have little increase in the price of market insurance even if there is a large negative market return. In such a case, the buyer (seller) is actually worse off (better off). We find that during market crashes both insurance buyers and sellers earn negative excess returns, consistent with both having positive unhedged market exposure. ${ }^{6}$ However, insurance buyers experience greater losses, consistent with the H-Bear factor being negative rather than positive during the most negative market return periods.

We find further evidence supporting the risk-based explanation of the H-Bear factor's predictive power. If low H-Bear beta funds earn higher returns on average by being exposed to bear market risk, we should observe an opposite, i.e., positive, relation between H-Bear beta and hedge fund returns during periods of high bear market risk, i.e., when bear market risk is realized. We define high bear market risk periods as months when the H-Bear factor is positive. In such cases, the increase (decrease) in the price for market insurance is higher (lower) than what would be justified by the concurrent negative (positive) market return. We observe a strong positive relation between H-Bear beta and future hedge fund returns during these months. In contrast, during the remaining months, the relation is negative and

\footnotetext{
${ }^{6}$ The finding is also consistent with the notion that hedge fund industry as a whole is exposed to substantial market downturns.
} 
statistically significant. Collectively, our findings lend further support to the idea that in the cross-section hedge funds who act as insurance sellers are exposed to bear market risk but are not necessarily always exposed to realized market tail risk.

Finally, we examine the determinants of hedge fund H-Bear exposure. Several findings are in line with prior evidence on the risk-taking behavior of hedge funds. For example, low H-Bear beta is associated with funds that are young, exhibit negative return skewness, and have higher past return. The results support the notion that young funds might have an incentive to attract fund flows by establishing a track record of high returns early in their life cycle. In addition, funds with low H-Bear beta are more likely to demand higher management fees and have a hurdle rate, which is consistent with risk-taking behavior responding to incentives. It is important to note that despite the fact that certain hedge fund characteristics help us understand the driving forces of the H-Bear sensitivity, none of them subsumes the negative relation between H-Bear beta and future fund returns.

A distinctive feature of our paper when compared to Gao, Gao, and Song (2018) is that it relies on the innovations in bear concerns instead of the current level of bear concerns. Specifically, Gao, Gao, and Song's (2018) RIX measure uses the average daily price of a put option portfolio within a month (which reflects the level of disaster concerns in their case) rather than the monthly return (which would reflect the change in concerns about future disasters). Intuitively, funds with high sensitivity to RIX exhibit high returns when the level/price of disaster concerns is high, and hence are considered skilled and are shown to outperform on average. We find that if we follow our approach and use the sensitivity to the return - and not to the price level - of the same S\&P 500 index put portfolio that is used in the RIX construction, this sensitivity predicts future hedge fund returns negatively rather than positively. In this case, we identify funds that have high returns when the return of a disaster insurance strategy is high. Such funds can be seen as insurance buyers and are 
expected to underperform on average. This result is in line with our main empirical evidence. It is important to note that the sensitivity of hedge fund returns to this "RIX return" factor does not absorb the relation between RIX betas and future hedge fund returns. Overall, the conclusions of the two studies are not inconsistent with each other. It is perfectly possible that the two effects, i.e., insurance sellers exploiting cases of overpriced insurance as Gao, Gao, and Song (2018) suggest and insurance sellers earning high returns by just being exposed to bear market (or disaster) risk as we suggest, coexist and complement each other.

Our study is related to a small but burgeoning literature that investigates the ability of various option-implied risk factors to explain the cross-section of hedge fund returns. ${ }^{7}$ Specifically, Agarwal, Bakshi, and Huij (2010), Buraschi, Kosowski, and Trojani (2014), and Agarwal, Arisoy, and Naik (2017) show that the higher order risk-neutral moments, correlation risk and volatility-of-volatility of the stock market, respectively, have significant explanatory power for future hedge fund returns. More generally, our paper is related to a series of studies that utilize the risk profile of hedge funds in order to explain their subsequent performance. Bali, Gokcan, and Liang (2007) document a positive relation between value-at-risk and future fund returns, Bali, Brown, and Caglayan (2011) show that the exposures to default premium and to inflation are significant predictors of hedge fund returns, Bali, Brown, and Caglayan (2012) show that funds with higher systematic risk are more profitable, while Bali, Brown, and Caglayan (2014) find that macroeconomic risk is priced in the cross-section. We contribute to the above two strands of the literature by proposing a novel option-implied predictor of hedge fund returns, i.e., the sensitivity to the

${ }^{7}$ In a different context, a series of studies, such as Fung and Hsieh (1997), Fung and Hsieh (2001), Amin and Kat (2003), Agarwal and Naik (2004), Agarwal, Bakshi, and Huij (2010), Jurek and Stafford (2015), and Agarwal, Arisoy, and Naik (2017), demonstrate option-like features inherent in the time-series return behaviour of many hedge fund investment styles. 
H-Bear factor, and unravelling the economic mechanism that associates this type of bear risk exposure with fund performance.

The rest of the paper is organized as follows. Section 2 discusses the data, the construction of the Bear portfolio, and the estimation of the hedge fund sensitivity to the H-Bear factor. Section 3 presents our main results by studying the effect of H-Bear sensitivity on future hedge fund returns, investigating the predictability across different states of nature, and examining the determinants of H-Bear factor exposure. Section 4 provides additional analyses. We perform a series of robustness checks in Section 5 and conclude in Section 6 .

\section{Data and variable construction}

\section{$2.1 \quad$ Hedge fund data}

Hedge fund data, including monthly hedge fund returns and fund characteristics, are from the Hedge Fund Research database (HFR), which is one of the leading sources of hedge fund information. In this database, we originally have information on a total of 25,976 live and defunct hedge funds. Since we construct the Bear portfolio returns using option data from OptionMetrics that are available from January 1996, the full sample period of hedge

fund returns that we use in this study is from January 1996 to December 2017. Following the literature, we retain monthly-filing funds and funds that report returns net of all fees and in US dollars.

Next, we make efforts to minimize the effects of potential data biases documented in the hedge fund literature (Fung and Hsieh, 2000; Liang, 2000; Edwards and Caglayan, 2001). First, to mitigate the backfilling bias, we follow Kosowski, Naik, and Teo (2007) to eliminate the first 12 months of a fund's return series. Furthermore, since this problem might be prevalent among small funds, we discard all funds with less than $\$ 10$ million of asset under management (AUM). Specifically, if a fund begins with less than $\$ 10$ million but later has 
$\$ 10$ million in AUM, we include the fund in the sample from the time its AUM reaches $\$ 10$ million and keep it in the sample as long as the fund exists regardless of its AUM. Second, monthly return histories of both live and defunct funds over the sample period are included, which helps minimize the survival bias. In Section 5, we perform a robustness check where we assume that returns of drop-out funds are $-100 \%$ following their last reporting month.

The above process leaves us with a final sample of 11,084 distinct hedge funds, of which 8,190 are defunct funds and the remaining 2,894 are live funds. More specifically, the period 1996-2007 experienced an exponential increase both in number of operating hedge funds, from 764 in 1996 to 4,583 funds at the end of 2007, and in total AUM, from around $\$ 109$ billion in 1996 to $\$ 1,549$ billion in 2007 . However, there was a sharp reversal in both of these figures starting in 2008 due to the financial crisis. By the end of 2017, there were 2,894 operating hedge funds with a total AUM of $\$ 1,211$ billion in our sample.

We follow Joenväärä, Kauppila, Kosowski and Tolonen (2021) to categorize hedge funds into ten primary strategies: event-driven, relative value, long-short equity, global macro, CTA, equity market-neutral, multi-strategy, short-bias, sector, and fund of funds. In terms of the number of funds, long-short equity is the largest strategy style, comprising 2,936 distinct hedge funds in our sample, whereas there are only 60 hedge funds falling into the short-bias strategy group. Table 1 presents descriptive statistics for our hedge fund sample.

[Insert Table 1 here]

Panel A of Table 1 reports the time-series average of the monthly cross-sectional mean, standard deviation, and percentiles of all individual hedge fund returns. On average, a fund earns $0.64 \%$ per month over the sample period with a standard deviation of $4.03 \%$. Among the ten main strategy categories, sector and long-short equity are the two strategies that 
yield the highest average monthly returns, $0.97 \%$ and $0.78 \%$ respectively, while short-bias hedge funds realize the lowest performance with an average return of $-0.15 \%$.

Panel B reports distribution statistics of cross-sectional hedge fund characteristics. The average AUM of individual hedge funds in our database is $\$ 175.22$ million, while the median size is $\$ 52.31$ million, implying that there are a few hedge funds with very large size. On average, an individual hedge fund operates for approximately 78 months or 6.5 years. Management fee and incentive fee are $1.44 \%$ and $15.78 \%$ on average, respectively. Hedge funds in our sample have an average lockup period of 3.46 months and require an average minimum investment of $\$ 1.26$ million.

\section{$2.2 \quad$ Bear portfolio}

\subsubsection{Data}

Data for S\&P 500 index options, including daily closing bid and ask quotes, trading volume and open interest for the period from January 1996 to December 2017, are obtained from OptionMetrics. We further collect the daily S\&P 500 index level and dividend yield, the VIX index level, and the risk-free rate. We apply several filters to the option data. First, to avoid illiquid options, we discard options if open interest is zero or missing, if the bid quote is zero, or if the bid quote is larger than the ask quote. Second, all options that violate noarbitrage conditions are excluded. Specifically, for a put option we require that the exercise price exceeds the best bid, which is in turn higher than $\max \left(0, K-S_{0}\right)$, where $K$ and $S_{0}$ are the option's strike price and the closing level of the S\&P 500 index respectively. Third, we only keep options with standard expiration dates.

We use the mid-point of the bid and ask quotes as a proxy for the market price of the

option contract. We further define the S\&P 500 index forward price to be $F=S_{0} e^{(r-y) T}$, 
where $r$ is the continuously compounded risk-free rate, $y$ is the dividend yield of the S\&P 500 index, and $T$ is the time to maturity.

\subsubsection{Bear portfolio construction}

We follow Lu and Murray (2019) and define an Arrow-Debreu bear security as a portfolio that pays $\$ 1$ when the S\&P 500 index level on a given date is in a bear state, and zero otherwise. We approximate this payoff structure from traded options by taking a long position in a put contract with strike price $K_{1}>K_{2}$ and a short position in a put contract with strike price $K_{2}$. After scaling both positions by $K_{1}-K_{2}$, the Bear portfolio will generate a payoff of $\$ 1$ at expiration if the index level is below $K_{2}$ and zero if the index level is above $K_{1}$. The payoff decreases linearly from $\$ 1$ to zero for index levels at expiration falling between $K_{2}$ and $K_{1}$. Thus, the Bear portfolio price, $P_{B E A R}$, is:

$$
P_{\text {BEAR }}=\frac{P\left(K_{1}\right)-P\left(K_{2}\right)}{K_{1}-K_{2}},
$$

where $P(K)$ is price of a put option with strike price $K$.

We choose $K_{2}$ to be 1.5 standard deviations bellow the S\&P 500 index forward price. The strike price $K_{2}$ establishes the bear region boundary, meaning that the market is in bear state when the market excess return is more than 1.5 standard deviations below zero. ${ }^{8} K_{1}$ is set to be one standard deviation below the S\&P 500 index forward price. ${ }^{9}$

${ }^{8}$ The 1.5 standard deviations point is chosen based on a trade-off between our objective of capturing significant downward market movements on the one hand, and the relative illiquidity of deep-out-of-themoney put options on the other hand. In Section 5, we show that the findings are very similar if we use different definitions of bear market regions.

${ }^{9}$ Although as $K_{1}$ approaches $K_{2}$, the payoff function of the Bear portfolio converges to the theoretical payoff of an Arrow-Debreu security, the spread between $P\left(K_{1}\right)$ and $P\left(K_{2}\right)$ also converges to zero and might be adversely affected by noise from option bid-ask spreads. Choosing $K_{1}-K_{2}$ to be half a standard deviation is based on a trade-off between these two considerations. 
The standard deviation of the market return is defined as $V \sqrt{T}$, where $V$ is the VIX index level divided by 100. Setting the standard deviation equal to VIX instead of using a constant volatility means that the bear market region under consideration is always adjusted for current market volatility levels. As a result, the price of the Bear portfolio, i.e., the discounted risk-neutral probability of a bear market outcome, remains roughly the same at each portfolio formation period. The return of the portfolio captures innovations in bear market concerns.

In the same vein with Lu and Murray (2019), we define $P\left(K_{1}\right)$ and $P\left(K_{2}\right)$ to be the trading-volume weighted average price of puts with strike prices within a 0.25 standard deviation range of the target strikes, $K_{1}$ and $K_{2}$. We follow this procedure because traded option contracts with exact targeted strikes are unlikely to exist. In addition, the volumeweighted average put price over a range of strikes gives more weight to liquid put options whose prices are expected to be less affected by microstructure noise. More specifically, we take:

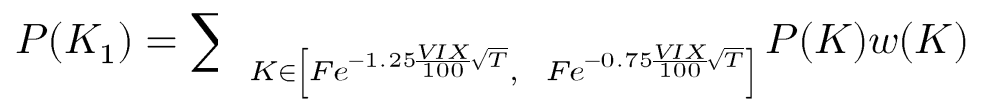

and

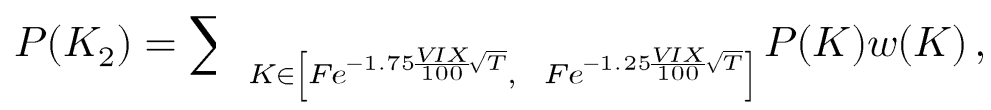

where $w(K)$ is the trading volume of a put option with strike price $K$ divided by the total trading volume of all put options in the indicated range.

\subsubsection{Bear portfolio returns and H-Bear factor}

Since returns of individual hedge funds in our database are available on a monthly basis, we also create a monthly Bear portfolio return factor. Specifically, on the last trading day of each month from January 1996 to November 2017, we buy the Bear portfolio using put 
options that have the shortest maturity among those with more than one month to expiration and calculate its price using the averages of closing bid-ask quotes of these options. ${ }^{10}$ We hold the portfolio for one month and measure its excess return by subtracting the onemonth risk-free rate from the one-month buy-and-hold return. In total, there are 264 monthly Bear portfolio excess returns for the period over 1996-2017.

\section{[Insert Table 2 here]}

Panel A of Table 2 reports the descriptive statistics for the monthly times-series of the Bear factor. Following Lu and Murray (2019), we scale the Bear factor to have the same volatility with the market factor. The average monthly excess return of the Bear factor is $-1.64 \%$ and is statistically significant with a t-statistic of -5.04 (as shown in the first column in Panel B of Table 2).

We further investigate whether the significantly negative Bear portfolio excess return is just simply the compensation for exposure to the market factor. In Panel B of Table 2, we perform a time-series regression of the Bear factor, $r_{B E A R, t}$, on the contemporaneous market excess returns, $M K T_{t}$, over January 1996 to December 2017. The regression is defined as:

$$
r_{B E A R, t}=\gamma+\delta \times M K T_{t}+\varepsilon_{t}
$$

where $\delta$ captures the exposure of the Bear portfolio to the market and $\gamma$ measures the average Bear portfolio excess return that is not explained by the market risk.

Consistent with its negative delta exposure, the Bear portfolio exhibits a significant market exposure with a coefficient on the market factor of -0.85 (t-statistic $=-15.90$ ) and an adjusted $\mathrm{R}^{2}$ of $72 \%$. Noticeably, the average adjusted return after controlling for the market

\footnotetext{
${ }^{10}$ For example, on 31/01/1996 we choose options that expire on 16/03/1996 to create the Bear portfolio. Out of 264 months, there are nine months for which we do not have available put options that meet these requirements. For these months, we form the Bear portfolio on the first trading day of the month (instead of the end of last month) and hold it until the month end.
} 
factor is $-1.09 \%$ per month and is statistically significant with a t-statistic of -6.77 . The finding implies that market factor exposure cannot fully capture the negative average return of the Bear portfolio. ${ }^{11}$ In other words, selling the market-hedged Bear (H-Bear) portfolio:

$$
r_{H-B E A R, t}=\gamma+\varepsilon_{t}=r_{B E A R, t}-\delta \times M K T_{t},
$$

is accompanied by a significant premium on average. Intuitively, the H-Bear factor is the component of the Bear portfolio return that is orthogonal to (or hedged with respect to) the market return, i.e., the intercept plus the residuals from a regression of the Bear portfolio returns on the market returns.

\subsection{Hedge fund exposure to the H-Bear factor}

Motivated by the negative premium of the market-hedged Bear portfolio and the "hedge" role of hedge funds, at the end of each month from December 1997 to November 2017 and for each hedge fund, we measure the hedge fund's exposure to the H-Bear factor by running the following time-series regression over a 24-month rolling window:

$$
r_{i, t}=\alpha_{i, t}+\beta_{i, t}^{H-B E A R} \times r_{H-B E A R, t}+\epsilon_{i, t},
$$

where $r_{i, t}$ is the excess return of fund $i$ in month $t$, and $r_{H-B E A R, t}$ is the H-Bear factor return estimated as per Equations (4)-(5) over the same 24-month window. We require at least 18 months of non-missing fund returns to ensure that we have a sufficient number of observations in the estimation. Note that the above regression provides exactly the same H-Bear beta, $\beta_{i, t}^{H-B E A R}$, with the following:

$$
r_{i, t}=\alpha_{i, t}+\beta_{i, t}^{M} \times M K T_{t}+\beta_{i, t}^{H-B E A R} \times r_{B E A R, t}+\epsilon_{i, t},
$$

\footnotetext{
${ }^{11}$ In an unreported analysis, we find that the Bear factor is not subsumed by other standard risk factors in the asset pricing and hedge fund literature (e.g., value, size, momentum, as well as the Fung and Hsieh (2004) seven factors).
} 
where $M K T_{t}$ is the CRSP value-weighted market excess return, and $r_{B E A R, t}$ is the return of the plain Bear portfolio.

By combining Equations (5) and (7) we get:

$$
r_{i, t}=\alpha_{i, t}+\beta_{i, t}^{M K T} \times M K T_{t}+\beta_{i, t}^{H-B E A R} \times r_{H-B E A R, t}+\epsilon_{i, t} .
$$

where $\beta_{i, t}^{M K T}=\left(\beta_{i, t}^{M}+\beta_{i, t}^{H-B E A R} \times \delta\right)$ captures the hedge fund's unhedged market exposure (i.e., market beta). In this way, the total risk exposure of a hedge fund can be seen as the combination of its unhedged market exposure and its exposure to the H-Bear factor.

$$
\text { [Insert Table } 3 \text { here] }
$$

Panel A of Table 3 presents the average $\beta_{i, t}^{H-B E A R}$ and $\beta_{i, t}^{M}$ of portfolios sorted on H-Bear beta. We find that there is a high dispersion in H-Bear betas among hedge funds, ranging from an average of -0.55 in the first quintile to an average of 0.53 in the fifth quintile. Because the Bear portfolio is considered as a market insurance, by construction, high (positive) H-Bear beta hedge funds act as insurance buyers, while low (negative) H-Bear beta hedge funds act as insurance sellers. We observe that insurance buyers have a high $\beta^{M}$ of 0.89 , while the insurance sellers have a slightly negative $\beta^{M}$ of -0.04 . This result is reasonable in the sense that the hedge funds that seek insurance are the ones already having some high exposure to the market. However, these $\beta^{M}$ values ignore that fact that the market and the Bear portfolio are highly negatively correlated. In fact, an insurance buyer (seller) reduces (increases) his overall market exposure by being long (short) the Bear portfolio.

Panel $\mathrm{B}$ of Table 3 shows that the average unhedged market exposures, $\beta_{i, t}^{M K T}=$ $\left(\beta_{i, t}^{M}+\beta_{i, t}^{H-B E A R} \times \delta\right)$, of the low and high H-Bear beta hedge funds are almost identical, at 0.43 . Collectively, the results can be interpreted as follows. Both insurance buyers and insurance sellers behave as if they are similarly exposed to the market factor, but insurance buyers obtain also a hedged long position to the market, while insurance sellers obtain also 
a hedged short position to the market. In that respect, any difference in their relative performance should be attributed to their differential exposure to the H-Bear factor. In other words, hedge funds with low H-Bear betas are expected to earn the negative premium of the H-Bear factor, and hence outperform on average the high H-Bear beta hedge funds that pay the premium.

Panel $\mathrm{C}$ of Table 2 provides summary statistics for the H-Bear factor. Note that in this case the H-Bear factor return for each month $t$ is obtained from a rolling regression of the Bear factor on the market factor over the past 24 months. Therefore, the average H-Bear return is slightly different from the constant term in the second column of Panel B, which was estimated using a full-sample regression. Still, both the average and the median H-Bear factor returns are highly negative, $-1.25 \%$ and $-1.69 \%$, respectively. Panel D of Table 2 and Figure 1 reveal that the negative premium of the H-Bear factor is distinct from realized tail risk. We find that the average H-Bear return during down and up market periods are respectively $-1.41 \%$ and $-1.16 \%$, while the average market return during periods of positive and negative H-Bear returns are respectively $1.69 \%$ and $0.24 \%$. The five highest (positive) market hedged Bear portfolio returns happen in August 1998, September 2000, February 2001, April 2002, and May 2012. During these months, the market excess returns were $16.08 \%,-5.45 \%,-10.05 \%,-5.20 \%$, and $-6.19 \%$, respectively. While these returns are all negative, with the exception of August 1998, those months are not the ones that experience the largest market losses. In fact, the average hedged Bear portfolio return in the five months with the most negative market returns over $1998-2017$ is $-0.22 \%$, which is negative rather than positive.

\section{[Insert Figure 1 here]}

These results are indicative of an important observation. While the returns of the market insurance are strongly affected by market movements, these two do not necessarily coincide. 
It is possible to have little increase (less than it should be) in the price of market insurance even if there is a large negative market return. In such a case, the buyer (seller) is actually worse off (better off). In the same vein, it is possible that there is a high increase in investors' fears about future bear market states even if there is little or no negative market return. In this case, the gain (loss) for the insurance buyer (seller) is high. Intuitively, when concerns about future bear market states increase, the increase (decrease) in insurance premium is more (less) than the decrease (increase) in market price, and vice versa. Therefore, the HBear factor reflects the increase in investors' concerns about future bear market states on top of what is justified by concurrent market returns. In that respect, the estimated hedge funds' exposure to H-Bear factor contains different information from hedge funds' exposure to realized market tail risk.

There is also a reason for which it is important to control for the market when estimating hedge fund exposure to bear market risk. In particular, if we do not do so, it will be impossible to correctly identify insurance buyers. As discussed above, high H-Bear beta funds have a high positive $\beta^{M}$ and the Bear portfolio and the market factor are highly negatively correlated. Therefore, if the market factor is excluded from Equation (7) or alternatively if we use the plain Bear portfolio instead of the H-Bear portfolio in Equation (6), the large positive exposure of insurance buyers to the market will dominate the positive exposure to the Bear portfolio and the H-Bear beta will turn negative. It is easy to see this by combining:

$$
M K T_{t}=\rho+\lambda \times r_{B E A R, t}+\zeta_{t},
$$

with Equation (7) to get:

$$
r_{i, t}=\alpha_{i, t}+\beta_{i, t}^{M} \times \rho+\left(\beta_{i, t}^{H-B E A R}+\beta_{i, t}^{M} \times \lambda\right) \times r_{B E A R, t}+\beta_{i, t}^{M} \times \zeta_{t}+\epsilon_{i, t}
$$

and noting that $\lambda$ is typically a number between -0.85 and -0.90 , while in the case of insurance buyers the average $\beta_{i, t}^{H-B E A R}$ is equal to 0.53 and the average $\beta_{i, t}^{M}$ is equal to 0.89 . 
In fact, Panel $\mathrm{C}$ of Table 3 shows that ignoring the market factor would cause the insurance buyers' exposure to the Bear factor, $\beta_{i, t}^{B E A R}=\left(\beta_{i, t}^{H-B E A R}+\beta_{i, t}^{M} \times \lambda\right)$, to become negative, at -0.27 . The problem is much less acute in the case of insurance sellers. Their exposure to the Bear portfolio estimated ignoring the market factor takes the value of -0.51 , which is similar to the value of -0.55 found when controlling for the market. The reason is that the average $\beta_{i, t}^{M}$ of insurance sellers is close to zero, at -0.04 , and hence $\left(\beta_{i, t}^{H-B E A R}+\beta_{i, t}^{M} \times \lambda\right)$ is a number very close to $\beta_{i, t}^{H-B E A R}$.

\section{H-Bear factor and hedge fund performance}

So far, we have shown that any systematic difference in relative performance of insurance sellers and buyers is expected to come from their differential exposure to the H-Bear factor - a proxy for bear market risk. This hedged factor is negative on average and is not correlated with market movements. Hence, we hypothesize that hedge funds with negative $\mathrm{H}-$ Bear betas - whose strategies resemble selling insurance - outperform on average by earning the negative premium of the H-Bear factor without being necessarily more exposed to market crashes. Instead, they underperform when bear market risk realizes (i.e., when concerns about future bear market states increase).

\subsection{Portfolio-level analysis}

At the end of each month from December 1997 to November 2017, we sort hedge funds into quintiles based on their exposure to the H-Bear factor. The fifth (first) quintile consists of funds with the highest (lowest) H-Bear betas. We also form a portfolio that goes long hedge funds in the fifth quintile and short hedge funds in the first quintile. We hold the portfolios for one month and measure their returns, which are from January 1998 to December 2017.

$$
\text { [Insert Table } 4 \text { here] }
$$


Panel A of Table 4 reports the results for the performance of hedge fund portfolios sorted by H-Bear beta. In particular, we present the time-series average of hedge fund returns across five quintiles. Each quintile has about 500 hedge funds on average and is well diversified. The average monthly equal-weighted hedge fund portfolio returns decline monotonically from $0.87 \%$ in the lowest H-Bear beta quintile to $0.29 \%$ in the highest H-Bear beta quintile. The average return difference between quintile 5 and quintile 1 is $-0.58 \%$ per month, or $-6.99 \%$ per year, with a t-statistic of -3.53 . To measure portfolio-level risk-adjusted returns (i.e., alphas), we perform a time-series regression of the monthly hedge fund portfolio returns in each quintile on the Fung and Hsieh (2004) seven factors, including three trend-following, two equity-oriented, and two bond-oriented risk factors (i.e., FTFSBD, PTFSFX, PTFSCOM, S\&P, SCMLC, BD10RET, and BAAMTSY). The regression is generally defined as:

$$
r_{P, t}=\alpha_{P}+\boldsymbol{\beta}_{\boldsymbol{P}}^{\prime} \times \boldsymbol{F}_{t}+\varepsilon_{P, t}
$$

where $r_{P, t}$ is month $t$ hedge fund portfolio return in each quintile and $\boldsymbol{F}_{t}$ is a vector of risk factors. We find that the Fung-Hsieh 7-factor alpha of the lowest H-Bear beta portfolio is $0.70 \%$ (with a t-statistic of 4.04 ) while that of the highest H-Bear beta portfolio is only $0.02 \%$ (with a t-statistic of -0.17 ). The resulting spread between alphas of quintile portfolios 5 and 1 is $-0.72 \%$ per month and is significant at all conventional levels with a t-statistic of -3.73 .

We further examine whether the return spread between quintile 5 and 1 can be explained by additional hedge fund risk factors. We modify Equation (11) by regressing equalweighted Q5-Q1 portfolio returns on the Fung and Hsieh (2004) and several additional risk factors. The results are presented in Panel B of Table 4.

For ease of comparison, we report the regression result based on the Fung and Hsieh (2004) seven-factor model as our baseline specification in the first column. These seven 
factor returns explain only $12 \%$ of the total variation in return difference between Q5 and Q1 over the period and none of them has a significant coefficient. In Specification (2), we include the HML (high-minus-low) and UMD (up-minus-down) factors from the Carhart (1997) model to control for book-to-market and momentum effects. In Specification (3), we further add the Pástor and Stambaugh (2003) traded liquidity factor to control for the liquidity exposure of hedge funds. In Specifications (4) to (7), we respectively include the returns of a long-short hedge fund portfolio with respect to the Bali, Brown, and Caglayan (2014) macroeconomic uncertainty factor, the Agarwal, Bakshi, and Huij (2010) risk-neutral volatility and skewness factors, the Gao, Gao, and Song (2018) RIX factor, and the Agarwal, Ruenzi, and Weigert (2017) tail risk measure. In Specification (8), we add all previously discussed factors. Across different specifications, our results always indicate a significant negative alpha (or risk-adjusted return) for the Q5-Q1 portfolio that ranges from $-0.49 \%$ to $-0.72 \%$ per month with the t-statistic ranging from -2.93 to -4.04 .

To summarize, there is a negative cross-sectional relation between H-Bear beta and expected hedge fund returns. Equivalently, hedge fund managers who choose to harvest the risk premium from selling bear risk insurance earn higher average returns than those who buy the bear risk insurance. Their significant outperformance cannot be explained by the exposure to standard risk factors documented in the hedge fund literature.

\section{$3.2 \quad$ Fund-level analysis}

The results from portfolio-level analysis demonstrate that a portfolio of hedge funds with low H-Bear beta yields significantly higher expected return than the one with high H-Bear beta. In this section, we perform Fama and MacBeth (1973) regressions that utilize the entire cross-sectional information in the data to examine whether the predictive power of H-Bear exposure for future hedge fund returns persists after simultaneously controlling for 
other hedge fund characteristics. In particular, each month from December 1997 to November 2017, we perform the following cross-sectional regressions:

$$
r_{i, t+1}=\psi_{0, t}+\psi_{t} \times \beta_{i, t}^{H-B E A R}+\phi_{t}^{\prime} \mathbf{Z}_{i, t}+\varepsilon_{i, t+1}
$$

where $r_{i, t+1}$ is the realized excess return of hedge fund $i$ in the month $t+1, \beta_{i, t}^{H-B E A R}$ is the H-Bear beta of hedge fund $i$ at the end of month $t$, and $\mathbf{Z}_{i, t}$ is a vector of fund characteristics. To distinguish the impact of H-Bear factor from other risk measures, we also include several hedge fund measures of risk. The details of these variables are provided in Appendix A.

Table 5 reports the time-series averages of the slope coefficients, the corresponding Newey-West adjusted t-statistics (with 24 lags), and the average adjusted $\mathrm{R}^{2}$ from 240 monthly regressions.

\section{[Insert Table 5 here]}

The univariate regression result in Specification (1) shows a negative relation between HBear beta and expected hedge fund returns. The average slope, $\psi_{t}$, from the monthly regressions of hedge fund returns on $\mathrm{H}-\mathrm{Bear}$ beta is -0.59 (t-statistic $=-3.63$ ). The economic magnitude of the H-Bear beta effect is comparable to that shown in the univariate portfoliolevel analysis. Specifically, multiplying the difference in mean values of H-Bear beta between the high and low H-Bear beta quintiles from Panel A of Table 3 by the slope coefficient yields a monthly risk premium differential of $-0.63 \%$ between the high and low H-Bear beta portfolios.

In Specification (2), we control for hedge fund characteristics, e.g., size, age, minimum investment amount, a fund's management and incentive fee, length of a fund's lockup and redemption period, as well as other measures of risk, e.g., past fund returns, fund return volatility, skewness, and kurtosis. We also add indicator variables that take the value of 
one in case the fund employs leverage, has a hurdle rate, has a high water mark, or is an offshore fund, and zero otherwise. In line with the prior literature, we find that minimum investment, past return, as well as past return volatility and skewness are positive and significant predictors of future hedge fund returns. More importantly, the association between H-Bear beta and future hedge fund returns remains negative (coefficient=-0.35) and statistically significant (t-statistic $=-3.72)$.

Next, we augment the above specification by including respectively in Specifications (3) to (5) the exposure to market risk, higher risk-neutral market moments (Agarwal, Bakshi, and Huij, 2010), and market tail risk (Agarwal, Ruenzi, and Weigert, 2017), all computed based on an estimation window of 24 months. Depending on the specification, the average coefficient estimate on $\mathrm{H}$-Bear beta ranges from -0.25 to -0.33 with t-statistics ranging from -3.24 to -3.33 . These results indicate that the above risk measures do not subsume the predictive power of H-Bear factor exposure for future hedge fund returns.

A potential explanation for the relation between H-Bear factor exposure and future hedge fund returns is that low H-Bear beta hedge fund managers have higher level of skills. In Specification (6), we control for several measures of hedge fund skills, including the macroeconomic uncertainty timing skill $\left(\beta^{U N C}\right)$ of Bali, Brown, and Caglayan (2014), the skill at exploiting rare disaster concerns $\left(\beta^{R I X}\right)$ of Gao, Gao and Song (2018), the R-squared measure of Titman and Tiu (2011), the strategy distinctiveness index (SDI) of Sun, Wang, and Zheng (2012), and the downside returns of Sun, Wang, and Zheng (2018). The average coefficient on H-Bear beta is still negative and statistically significant at the $1 \%$ level, confirming the distinctive effect of H-Bear factor exposure.

Of primary interest is Specification (7), where we control for the full set of hedge fund characteristics, exposures to other risk factors, and manager skill measures. The coefficient on $\mathrm{H}$-Bear beta remains negative, -0.29 , and is significant at all conventional levels with a 
t-statistic of -3.05. Overall, our results document a strong negative cross-sectional relation between H-Bear beta and future hedge fund returns. The effect is not subsumed by hedge fund characteristics, manager skills, and fund exposures to previously documented risk factors.

\subsection{Effect of H-Bear factor exposure during different market states}

\subsubsection{Market crashes versus normal times}

To examine whether hedge funds with negative H-Bear betas - whose trading strategies are associated with selling insurance - are more or less exposed to market crashes, we investigate the association between H-Bear beta and hedge fund returns during market crash periods versus normal periods. Market crashes are defined as months during which the market excess return is lower than its $10^{\text {th }}$ percentile over the sample period. ${ }^{12}$ We use a specification identical to that in Specification (7) of Table 5 to control for a large set of fund characteristics, manager skill measures, and risk exposures. We report the coefficients on H-Bear beta and market beta but suppress the coefficients on other control variables for the sake of brevity.

[Insert Table 6 here]

Specification (1) of Table 6 shows a strong negative relation between H-Bear beta and hedge fund returns (coefficient of -1.15 and t-statistic of -2.75 ) during market crash periods, which is robust to controlling for market beta that captures hedge funds' unhedged market exposure. This is consistent with the idea that the H-Bear factor is negative on average even during market crashes, i.e., low H-Bear beta funds still earn the negative premium of

\footnotetext{
${ }^{12}$ We obtain similar results using alternative definitions of realized market crashes, e.g., when excess market returns are lower than $-10 \%$, when excess market returns are lower than the sample period $5^{\text {th }}$ percentile, and during the recession periods indicated by the National Bureau of Economic Research (NBER).
} 
this factor. For example, during the October 2008 crisis, the market experienced an excess return of $-17.23 \%$, but the $\mathrm{H}-$ Bear factor also had a negative return of $-4.27 \%$. Accordingly, low (negative) H-Bear beta funds who act as insurance sellers earn an average excess return of $-5.31 \%$, while high (positive) H-Bear beta funds who act as insurance buyers happen to underperform with an average excess return of $-10.01 \% .^{13}$ During normal times, as in Specification (2), we still observe a significant negative effect of H-Bear beta on future hedge fund returns with the coefficient on H-Bear beta equal to -0.20 (t-statistic $=-1.83$ ).

Similarly, we examine the predictive power of H-Bear factor exposure during months when the market excess returns are negative versus positive. The regression result from Specification (3) in Table 6 shows a negative and significant relation between H-Bear beta and hedge fund returns when the market declines. The average coefficient on H-Bear beta during these months is -0.67 (t-statistic $=-2.62$ ). When the market excess returns are positive as shown in Specification (4), we still find a negative association, but it is not statistically significant (the average $\mathrm{H}$-Bear beta coefficient $=-0.06$, t-statistic $=-0.42$ ). One potential explanation for the less pronounced negative H-Bear beta effect during the positive market return periods is that on some occasions, positive market returns are accompanied by persistently increase in concerns about future bear market states (for example, in periods when the market rebounds) and hence coincide with periods of positive H-Bear factor.

In contrast, in the same regressions, we find that the impact of market beta on future hedge fund returns is significantly negative in periods of market crashes or in periods of negative market returns (Specifications (1) and (3)), but strongly positive during normal

\footnotetext{
${ }^{13}$ The evidence that both low and high H-Bear beta groups of hedge funds experience significant losses when the market crashes is understandable because both groups have positive unhedged market exposure (see again Section 2.3). This is also aligned with the notion that hedge funds on an aggregate level are exposed to substantial market downturns (see Agarwal and Naik, 2004; Jurek and Stafford, 2015). Also, using portfoliolevel analysis, we find that high H-Bear beta quintile underperforms low H-Bear beta quintile by an average of $2.85 \%$ per month during the market crash periods and by an average of $1.16 \%$ per month during the negative market return periods. Results are available upon request.
} 
times or when market returns are positive (Specifications (2) and (4)). This opposite-sign relation is expected: hedge funds with high unhedged market (or realized tail risk) exposure earn premium during normal times but perform worse when the market declines (or when tail risk materializes) (see Jiang and Kelly, 2012; Agarwal, Ruenzi, and Weigert, 2017). Therefore, the effect of H-Bear beta on hedge fund returns is distinct and far from fully explained by either market or realized tail risk exposure.

Overall, our findings suggest that negative H-Bear beta funds who act as (hedged) insurance sellers do not necessarily underperform positive H-Bear beta funds who act as (hedged) insurance buyers during market crashes. This provides additional insights into the crosssectional aspects of option-like hedge fund returns.

\subsubsection{Positive versus negative H-Bear factor}

As low H-Bear beta funds earn higher returns on average by being more exposed to bear market risk, we expect an opposite, i.e., positive, relation between H-Bear beta and hedge fund returns when such risk is realized (i.e., when concerns about future bear market states increase). We define the periods of realized (unrealized) bear market risk as months when the H-Bear factor returns are positive (negative). We then examine the H-Bear factor exposure effect conditional on these different states and report the results in Table 7 .

\section{[Insert Table 7 here]}

As expected in Specification (1) of Table 7, we find that the effect of H-Bear beta on future hedge fund returns is strongly negative in periods of negative H-Bear factor returns (when bear market risk is not realized). In particular, the average coefficient on H-Bear beta is -0.49 with a corresponding t-statistic of -3.50 . However, in Specification (2) of Table

7, the relation reverses and becomes positive, with an average H-Bear beta coefficient of 0.44 and a t-statistic of 3.16, during periods of positive H-Bear factor returns (when bear 
market risk is realized). ${ }^{14}$ These results are in line with the following economic mechanism. When the H-Bear return is negative, the price of insurance does not increase enough to compensate for the negative market return or decreases more than what is expected given a positive market return. In this case, hedge funds with negative H-Bear betas (insurance sellers) outperform hedge funds with positive H-Bear betas (insurance buyers). Oppositely, when the H-Bear return is positive (i.e., there is an increase in concerns about future bear market states), the insurance return exceeds in absolute terms the negative market return or decreases less than what is expected given a positive market return. In this case, we find that funds with positive H-Bear betas (insurance buyers) outperform funds with negative H-Bear betas (insurance sellers).

To better understand these results, recall from Panel B of Table 3 that the return of an insurance buyer (seller) comprises a positive unhedged position and a hedged long (short) position to the market. Also, both groups have equivalent unhedged market exposure, which is around 0.43 . Hence, the relative outperformance or underperformance of each hedge fund group in different periods is purely attributed to its differential exposure to the H-Bear factor.

\subsection{Determinants of H-Bear factor exposure}

To further understand which funds are more or less likely to be exposed to bear market risk, we next examine which fund characteristics and other risk measures are associated with HBear beta. We perform a series of Fama and MacBeth (1973) regressions of the H-Bear beta of hedge fund $i$ in month $t$ on various contemporaneous characteristics and risk measures of fund $i$ :

\footnotetext{
${ }^{14}$ Since the periods of negative H-Bear factor are markedly more than the periods of positive H-Bear factor (189 versus 51 months, respectively), the negative relation between H-Bear beta and future hedge fund returns is the one that dominates in the overall sample period.
} 


$$
\beta_{i, t}^{H-B E A R}=\alpha_{t}+\phi_{t}^{\prime} \mathbf{Z}_{i, t}+\varepsilon_{i, t},
$$

where $\beta_{i, t}^{H-B E A R}$ is the H-Bear beta of hedge fund $i$ in the month $t$, and $\mathbf{Z}_{i, t}$ is a vector of fund characteristics. Table 8 reports the time-series averages of the slope coefficients and the corresponding Newey-West adjusted t-statistics (with 24 lags).

\section{[Insert Table 8 here]}

Specification (1) of Table 8 investigates the association between H-Bear beta and timevarying fund characteristics such as fund size, age, return volatility, skewness, kurtosis and past yearly return. We find that hedge funds with low H-Bear betas tend to be younger. Intuitively, young funds probably have incentives to attract fund flows by establishing a track record of high returns early in their life cycle. Thus, these funds are more likely to get involved in trading strategies that resemble selling market insurance since it offers high compensation. Furthermore, consistent with risk-inducing behavior, there is a positive relation between H-Bear beta of hedge funds and their return skewness. Equivalently, low HBear beta funds, which are more exposed to bear market risk, exhibit left-skewed return distributions. However, despite having more negative return skewness, these funds have higher past-year returns.

In Specification (2), we include time-invariant contractual features such as a fund's minimum investment amount, management and incentive fees, lockup and redemption periods, as well as indicator variables that equal one if a given fund is offshore, employs leverage, has a high-water mark and a hurdle rate. Intuitively, hedge funds with low H-Bear betas are associated with measures of managerial incentives such as high management fees, existence of a hurdle rate, and offshore location. There is a positive relation between fund $\mathrm{H}_{-}$ Bear beta and incentive fee, but this finding is consistent with Agarwal, Daniel, and Naik (2009) who find that incentive fees do not capture managerial incentives as two managers 
charging the same incentive fee can face different dollar incentives. We find a mixed relation between H-Bear beta and managerial discretion. Specifically, funds with low H-Bear betas have longer redemption periods and are probably more flexible in taking on riskier positions, but are less likely to employ leverage. Intuitively, hedge funds that employ leverage tend to act more as insurance buyers, probably because their trading profile is already quite risky. In contrast, unlevered hedge funds tend to act more as insurance sellers probably because they find alternative ways to boost their returns rather than employing leverage.

In Specification (3), we include all fund characteristics and contractual features together in the same regression model. Although, the statistical significance of some of the variables is reduced, the main findings about the determinants of H-Bear beta remain intact.

\section{Further analysis}

\subsection{H-Bear factor exposure and long-term future hedge fund returns}

We further investigate how strong the exposure to $\mathrm{H}$-Bear factor is in terms of predicting long-term future hedge fund returns. From a practical point of view, this is important because some investors and hedge fund managers might be more interested in long-term investment horizons. Indeed, lockup periods for hedge fund managers can be sometimes up to one year.

[Insert Table 9 here]

First, we perform a univariate portfolio analysis, similar to that presented in Table 4, but we focus on the predictability for the return of month $t+k$, with $k$ ranging from 2 to 9 , rather than the return of month $t+1$. Panel A of Table 9 presents the results. As expected, the magnitude of the return differentials (in absolute terms) becomes smaller as the gap between the month when H-Bear beta-sorted portfolios are generated and the month when the performance of those portfolios is evaluated increases. However, the return and alpha 
spreads are all negative and statistically significant up to the eighth month. In the ninth month, the alpha spread is still negative, but not significant at the $5 \%$ level. Overall, $\mathrm{H}-$ Bear factor exposure is a persistent predictor of future hedge fund returns since its predictive power lasts for up to eight months ahead.

Next, we examine the returns of H-Bear beta-sorted portfolios by holding them for longterm horizons ranging from 3 months to 24 months. We follow Jegadeesh and Titman (1993) and implement the independently managed portfolio strategy to address the returns from overlapping holding periods. Panel B of Table 9 reveals a significant performance persistence for up to 24 months ahead, with return spreads between high and low H-Bear beta funds of $-0.58 \%,-0.49 \%,-0.30 \%$, and $-0.18 \%$ per month for a holding horizon of three, six, twelve, and twenty-four months, respectively. Moreover, these return differences are statistically significant at the $5 \%$ level, showing that H-Bear beta can successfully predict long-horizon cumulative hedge fund returns for up to 24 months into the future.

Fund returns are often reported with a lag and it takes some time to start an investment into a hedge fund. Considering this practical issue in investing in hedge funds, we implement a portfolio strategy that is identical to that in Panel B except that we now leave a onemonth gap between the portfolio formation month and the month in which portfolio returns start being calculated. The results reported in Panel $\mathrm{C}$ of Table 9 are similar to those presented in Panel B. In particular, we still observe a significant outperformance of low HBear beta hedge funds compared to high H-Bear beta hedge funds even when considering an 18-month holding period.

\section{$4.2 \quad$ H-Bear factor exposure conditional on investment styles}

To provide some insights as to whether the predictive power of H-Bear factor for future hedge fund returns is an inter- versus intra-style effect, we examine the performance (returns 
and alphas) of portfolios sorted based on their H-Bear factor exposures separately using funds within each investment style. Table 10 presents the results.

[Insert Table 10 here]

We exclude the short-bias category because, as shown in Table 1, we do not have enough observations to perform a meaningful analysis. Table 10 shows that there is a high variation in H-Bear betas within each hedge fund investment style. Consistent with this finding, we further observe a strong and negative relation between H-Bear beta and portfolio returns in all the nine investment styles. Among the most significant styles, return spreads between the high and low H-Bear beta quintiles are $-0.72 \%$ per month for relative value, $-0.70 \%$ for global macro, and $-0.61 \%$ for multi-strategy. The corresponding alpha differentials are also economically substantial and statistically significant. The return and associated alpha spreads are lower among equity market-neutral, fund of funds, and long-short equity funds, but they are all statistically significant. In summary, there is a high variation in the H-Bear factor exposure within each investment style and hedge funds seem to exhibit both interand intra-style bear market risk pricing.

\section{$4.3 \quad \mathrm{H}$-Bear factor exposure versus manager skills at exploiting rare disaster concerns}

In a related study, Gao, Gao, and Song (2018) also use a positioning in put options (see their Equation (4)) in order to capture investors' perceptions about market-wide tail risk and show that hedge funds with high sensitivity to a rare disaster concern index (RIX) earn on average higher returns than hedge funds with low sensitivity to the RIX index. Their put portfolio is more complicated and is designed to capture extreme negative price movements. In contrast, our Bear portfolio is simpler, and the level of extreme returns captured can be easily adjusted. Despite this difference, the two put option portfolios are conceptually 
similar. Therefore, it is important to understand why the results of our paper are different from theirs.

Gao, Gao, and Song's (2018) RIX index is the average daily price within a month of a portfolio of put options on various indices from sectors including banking, semiconductor, precious metals, housing, oil service, and utilities. Hedge funds' sensitivity to this measure $\left(\beta^{R I X}\right)$ is interpreted as skill in exploiting the market's ex-ante rare disaster concerns. ${ }^{15}$ In contrast, the Bear factor is the monthly return of a portfolio of put options (accordingly, the H-Bear factor can be interpreted as the return of a market-hedged put option portfolio). As a result, it captures the return of an insurance contract against concerns about future bear market states. Our conjecture is that the difference in the results of the two papers comes from the different approaches in using average prices within the month versus monthly returns and not from the different portfolio of puts that is used in each paper. This implies that if we use the return - rather than the price level - of the same portfolio of put options that form the RIX index, we will get a predictive pattern that resembles the one presented in this paper.

[Insert Table 11 here]

Panel A of Table 11 presents the results from a portfolio sorting exercise based on hedge fund sensitivities to various versions of the RIX index estimated controlling for the market excess returns. For consistency with Gao, Gao and Song's (2018) study, all the results span the period from January 1998 to December 2011 and are based on decile portfolios. Specification (1) uses the RIX index that is made publicly available by George Gao and covers the period 1996-2011. We observe a pattern that is very close to what is reported in Gao,

\footnotetext{
${ }^{15} \mathrm{Gao}$, Gao and Song's (2018) finding does not point to a risk-based explanation. RIX is persistent with an autocorrelation coefficient of 0.92 , which is not a risk factor per se as the innovations in concerns about future bear market states.
} 
Gao and Song (2018). Specification (2) presents the result of the same analysis but with our replication of the RIX index. Our RIX index has a $99 \%$ correlation with the RIX index provided by Gao and hence, as expected, the results are very close to Specification (1). Specification (3) shows the results using a RIX index constructed using only S\&P 500 index options - rather than using a mixture of six indices as in the main RIX. Similar to Gao, Gao, and Song (2018) (see their Internet Appendix), we find a positive albeit less significant association between the sensitivity to this RIX index and hedge fund returns. Overall, high RIX beta funds, on average, outperform low RIX beta funds and they are able to avoid significant losses when market crashes occur. According to Gao, Gao, and Song (2018), this is because these high RIX beta funds skilfully time the selling of overpriced crash insurance.

Specification (4) in Panel A of Table 11 shows the main result of this section. We construct an investable disaster concern factor from a portfolio of S\&P 500 put options as in Equation (4) in Gao, Gao, and Song (2018). The factor captures the return of the put option portfolio, rather than the average daily price within the month. The option positions are formed on a daily basis, and the daily returns within the month are averaged to create the monthly RETRIX. The construction of this investable factor is detailed in Appendix A. We argue that the covariance between hedge fund returns and the returns, rather than the contemporaneous price levels, of a portfolio of put options provides an intuitive way to classify hedge funds as insurance buyers or sellers. Now, we observe that the pattern is reversed and there is a negative and significant association between sensitivity to RETRIX $\left(\beta^{R E T R I X}\right)$ and future hedge fund returns. Furthermore, in line with our main empirical evidence, insurance sellers still outperform insurance buyers during periods of market crashes. However, this is not because these insurance sellers have higher skills, but because they are mechanically more exposed to bear market (or disaster) risk. 
It is reasonable to ask whether $\beta^{R E T R I X}$ absorbs the positive effect of $\beta^{R I X}$ on future hedge fund returns. To answer this question, we report in Panel B of Table 11 two sets of bivariate dependent sorts according to $\beta^{R E T R I X}$ and $\beta^{R I X}$. In Panel B.1, we first sort all hedge funds into quintiles based on their RETRIX betas, and then within each RETRIX beta quintile, we further sort funds into five portfolios based on their RIX betas. We observe the outperformance of high RIX beta funds relative to low RIX beta funds in all RETRIX beta quintiles, even in the high RETRIX beta group that is classified as buying insurance. Possibly, RIX beta reflects a skillful timing of selling crash insurance rather than a blind selling of it, thus containing a different information from the exposure to bear market risk. In Panel B.2, when we first sort hedge funds based on RIX betas into quintiles and then sorts funds within each RIX beta quintile into five RETRIX beta portfolios, we still observe the outperformance of low RETRIX beta funds relative to high RETRIX beta funds within each RIX beta quintile. The risk-adjusted return spreads of high-minus-low RETRIX beta portfolios range from $-0.33 \%$ to $-0.83 \%$ per month, all statistically significant at the $5 \%$ level.

Overall, the results of this section show that the exact portfolio of put options that is used to capture negative market movements is of secondary importance for analyzing the cross-section of hedge fund returns. What is of primary importance is whether we consider the average price of this portfolio (the sensitivity to which reflects skill according to Gao, Gao, and Song (2018)) or the return of this portfolio (the sensitivity to which reveals whether a hedge fund acts more as an insurance buyer or seller).

\section{Robustness checks}

In this section, we further corroborate our findings in the paper by conducting a battery of robustness checks on the predictive power of H-Bear beta for one-month ahead hedge fund returns based on portfolio-level analyses. 
[Insert Table 12 here]

First, instead of examining equal-weighted returns as in our baseline analysis, we use value-weighted returns. Specification (1) of Table 12 shows that the H-Bear factor effect is both statistically and economically significant when portfolio returns are weighted by AUM. For example, the underperformance of hedge funds in the highest H-Bear beta, compared to the lowest H-Bear beta, quintile is economically large, generating an average return spread of $-0.63 \%$ per month with a t-statistic of -3.42 . The associated alpha difference between these two quintiles is $-0.73 \%$ per month and also statistically significant.

Second, we examine the stability of our results by changing the H-Bear beta estimation horizon from 24 months to either 12 or 36 months. As shown in Specifications (2) and (3) of Table 12, the Q5-Q1 portfolio return spreads are $-0.50 \%$ and $-0.42 \%$ per month for a $\mathrm{H}-$ Bear beta estimation horizon of 12 months and 36 months, respectively. The corresponding t-statistics are -2.75 and -4.30 . The risk-adjusted returns of the Q5-Q1 H-Bear beta portfolio based on the Fung and Hsieh (2004) seven factor model are also negative and statistically significant at the $1 \%$ level in both specifications.

Third, we investigate whether our results are robust to alternative definitions of the Bear portfolio. In Specifications (4) and (5) of Table 12, we define bear region as states in which the market excess return is one or two standard deviations, instead of 1.5 standard deviations, below zero. We still find significantly negative return and Fung-Hsieh alpha differences between the portfolio of high $\beta_{1 \sigma}^{H-B E A R}$ (or $\beta_{2 \sigma}^{H-B E A R}$ ) hedge funds and the portfolio of low $\beta_{1 \sigma}^{H-B E A R}$ (or $\beta_{2 \sigma}^{H-B E A R}$ ) hedge funds. Next, we use only the long put position by dropping the short put position from the Bear portfolio. This put portfolio is simpler and conceptually closer to the portfolio utilized by Agarwal and Naik (2004). As shown in Specification (6) of Table 12, the portfolio of low $\beta^{H-P U T}$ hedge funds outperforms the portfolio of high $\beta^{H-P U T}$ hedge funds with significant return and alpha differences. In an unreported 
analysis, we also find that hedge funds with low $\beta^{H-P U T}$ still outperform hedge funds with high $\beta^{H-P U T}$ during periods of market crashes.

Finally, as a way to mitigate survivorship bias, in Specification (7) of Table 12 we repeat the baseline analysis by assuming that returns of the drop-out funds are $-100 \%$ in the month following the last reporting month. This is because the HFR database does not report delisting hedge fund returns. This delisting return assumption does not change our conclusion. For instance, the return and alpha spreads between Q5 and Q1 are $-0.80 \%$ (t-statistic of 4.41 ) and $-0.93 \%$ (t-statistic of -4.46$)$, respectively. Besides, our results are not materially affected when we assign different values for delisted hedge fund returns, such as $-75 \%,-$ $50 \%,-25 \%$, and zero.

\section{Conclusion}

In this paper, we document that exposure of hedge funds to the market-hedged Bear factor can explain a large proportion of the cross-sectional variation in their returns. We show that, despite a strong negative relation, the market and the Bear portfolio do not move in lockstep. Thus, the relative price movement between the two, captured by return of the $\mathrm{H}-$ Bear, is a proxy for the innovation in ex-ante concerns about future bear market on top of what is justified by the concurrent market return. By construction, hedge funds with positive (negative) exposure to the H-Bear factor are quantified as hedged insurance buyers (sellers). In fact, we find that when we take into consideration the hedge funds' insurancerelated positions, the unhedged market exposure of both hedge fund groups is almost identical. Therefore, any differences in their expected returns are naturally attributed to their differential exposure to the H-Bear factor.

In a portfolio-level analysis, hedge funds in the lowest H-Bear beta quintile (insurance sellers) outperform hedge funds in the highest H-Bear beta quintile (insurance buyers) by 0.58\% per month an average. The risk-adjusted return difference between these two hedge 
fund quintiles remains economically large and statistically significant. Results from multivariate regressions reveal a negative and statistically significant effect of $\mathrm{H}$-Bear beta on future hedge fund returns after controlling for a large set of fund characteristics and risk attributes. Therefore, the explanatory power of the H-Bear factor exposure is distinct from previously documented hedge fund return predictors.

Our interpretation for the above findings is that low H-Bear beta funds earn higher returns on average by harvesting the bear market risk premium, while high H-Bear beta funds earn lower returns on average because they willingly pay this insurance premium. Consistent with our risk-based explanation, the relation between H-Bear beta and future fund returns is reversed and becomes positive during months when bear market risk materializes (i.e., positive H-Bear returns). In contrast, the association remains negative in the rest of the periods, and even in periods of negative market returns or during market crashes. Overall, our evidence shows that in the cross-section, low H-Bear beta hedge funds who act as insurance sellers outperform high H-Bear beta hedge funds who act as insurance buyers by being more exposed to bear market risk, but without necessarily being more exposed to realized market tail (crash) risk. 


\section{References}

Agarwal, V., Arisoy, Y. E., Naik, N. Y., 2017. Volatility of aggregate volatility and hedge fund returns. Journal of Financial Economics 125, 491-510.

Agarwal, V., Bakshi, G., Huji, J., 2010. Do higher-moment equity risks explain hedge fund returns? Unpublished working paper, Georgia State University, University of Maryland, and Erasmus University.

Agarwal, V., Daniel, N. D., Naik, N. Y., 2009. Role of managerial incentives and discretion in hedge fund performance. Journal of Finance 64, 2221-2256.

Agarwal, V., Naik, N. Y., 2004. Risks and portfolio decisions involving hedge funds. Review of Financial Studies 17, 63-98.

Agarwal, V., Ruenzi, S., Weigert, F., 2017. Tail risk in hedge funds: A unique view from portfolio holdings. Journal of Financial Economics 125, 610-636.

Amin, G., Kat, H., 2003. Hedge fund performance 1990-2000: Do the money machines really add value? Journal of Financial and Quantitative Analysis 38, 251-274.

Ang, A., 2014. Asset management: A systematic approach to factor investing. Oxford University Press.

Aragon, G., Martin, S., 2012. A unique view of hedge fund derivatives usage: Safeguard or speculation? Journal of Financial Economics 105, 436-456.

Arrow, K. J., 1964. The role of securities in the optimal allocation of risk-bearing. Review of Economic Studies 31, 91-96.

Bakshi, G., Kapadia, N., Madan, D. B., 2003. Stock return characteristics, skew laws, and differential pricing of individual equity options. Review of Financial Studies 16, 101-143.

Bali, T. G., Brown, S. J, Caglayan, M. O., 2011. Do hedge funds' exposures to risk factors predict their future returns? Journal of Financial Economics 101, 36-68.

Bali, T. G., Brown, S. J, Caglayan, M. O., 2012. Systematic risk and the cross section of hedge fund returns. Journal of Financial Economics 106, 114-131. 
Bali, T. G., Brown, S. J., Caglayan, M. O., 2014. Macroeconomic risk and hedge fund returns. Journal of Financial Economics 114, 1-19.

Bali, T. G., Gokcan, S., Liang, B., 2007. Value at risk and the cross-section of hedge fund returns. Journal of Banking and Finance 31, 1135-1166.

Buraschi, A., Kosowski, R., Trojani, F., 2014. When there is no place to hide: correlation risk and the cross-section of hedge fund returns. Review of Financial Studies 27, 581-616.

Carhart, M. M., 1997. On persistence in mutual fund performance. Journal of Finance 52, $57-82$.

Debreu, G., 1959. Theory of value: An axiomatic analysis of economic equilibrium. No. 17, Yale University Press.

Edwards, F. R., Caglayan, M. O., 2001. Hedge fund performance and manager skill. Journal of Futures Markets 21, 1003-1028.

Fama, E. F., French, K. R., 1993. Common risk factors in the returns on stocks and bonds. Journal of Financial Economics 33, 3-56.

Fama, E. F., MacBeth, J. D., 1973. Risk, return, and equilibrium: Empirical tests. Journal of Political Economy 81, 607-636.

Fung, W., Hsieh, D. A., 2001. The risk in hedge fund strategies: Theory and evidence from trend followers. Review of Financial Studies 14, 313-341.

Fung, W., Hsieh, D. A., 1997. Empirical characteristics of dynamic trading strategies: The case of hedge funds. Review of Financial Studies 10, 275-302.

Fung, W., Hsieh, D. A., 2000. Performance characteristics of hedge funds and commodity funds: Natural and spurious biases. Journal of Financial and Quantitative Analysis 35, 291-307.

Fung, W., Hsieh, D. A., 2004. Hedge fund benchmarks: A risk-based approach. Financial Analysts Journal 60, 65-80.

Gao, G. P., Gao, P., Song, Z., 2018. Do hedge funds exploit rare disaster concerns? Review of Financial Studies 31, 2650-2692. 
Jegadeesh, N., Titman, S., 1993. Returns to buying winners and selling losers: Implications for stock market efficiency. Journal of Finance 48, 65-91.

Jiang, H., Kelly, B., 2012. Tail risk and hedge fund returns. Unpublished working paper. Erasmus University and University of Chicago Booth School of Business.

Joenväärä, J., Kauppila, M., Kosowski, R., Tolonen, P., 2021. Hedge fund performance: Are stylized facts sensitive to which database one uses? Critical Financial Review 10, 271327.

Jurek, J.W., Stafford, E., 2015. The cost of capital for alternative investments. Journal of Finance 70, 2185-2226.

Kosowski, R., Naik, N. Y., Teo, M., 2007. Do hedge funds deliver alpha? A Bayesian and bootstrap analysis. Journal of Financial Economics 84, 229-264.

Liang, B., 2000. Hedge funds: The living and the dead. Journal of Financial and Quantitative Analysis 35, 309-326.

Lu, Z., Murray, S., 2019. Bear beta. Journal of Financial Economics 131, 736-760.

Newey, W. K., West, K. D., 1987. A simple, positive semi-definite, heteroskedasticity and autocorrelation consistent covariance matrix. Econometrica 55, 703-708.

Pástor, L., Stambaugh, R., 2003. Liquidity risk and expected stock returns. Journal of Political Economy 111, 642-685.

Stulz, R. M., 2007. Hedge funds: Past, present, and future. Journal of Economic Perspectives $21,175-194$.

Sun, Z., Wang, A., Zheng, L., 2012. The road less travelled: Strategy distinctiveness and hedge fund performance. Review of Financial Studies 25, 96-143.

Sun, Z., Wang, A., Zheng, L., 2018. Only winners in tough times repeat: Hedge fund performance persistence over different market conditions. Journal of Financial and Quantitative Analysis 53, 2199-2225.

Titman, S., Tiu, C., 2011. Do the best hedge funds hedge? Review of Financial Studies 24, $123-168$. 
Figure 1: Time-series of market hedged Bear factor

The figure plots the monthly time-series of the market-hedged Bear portfolio (i.e., H-Bear) returns over January 1998 to December 2017. H-Bear return in month $t$ is equal to the intercept coefficient plus the month $t$ residual from a regression of the Bear portfolio excess returns on the market excess returns over the past 24 months. Bear portfolio excess return (Bear factor) is the one-month buy-and-hold excess return of a bear spread portfolio that longs an OTM put and shorts a further OTM put on the S\&P 500 index.

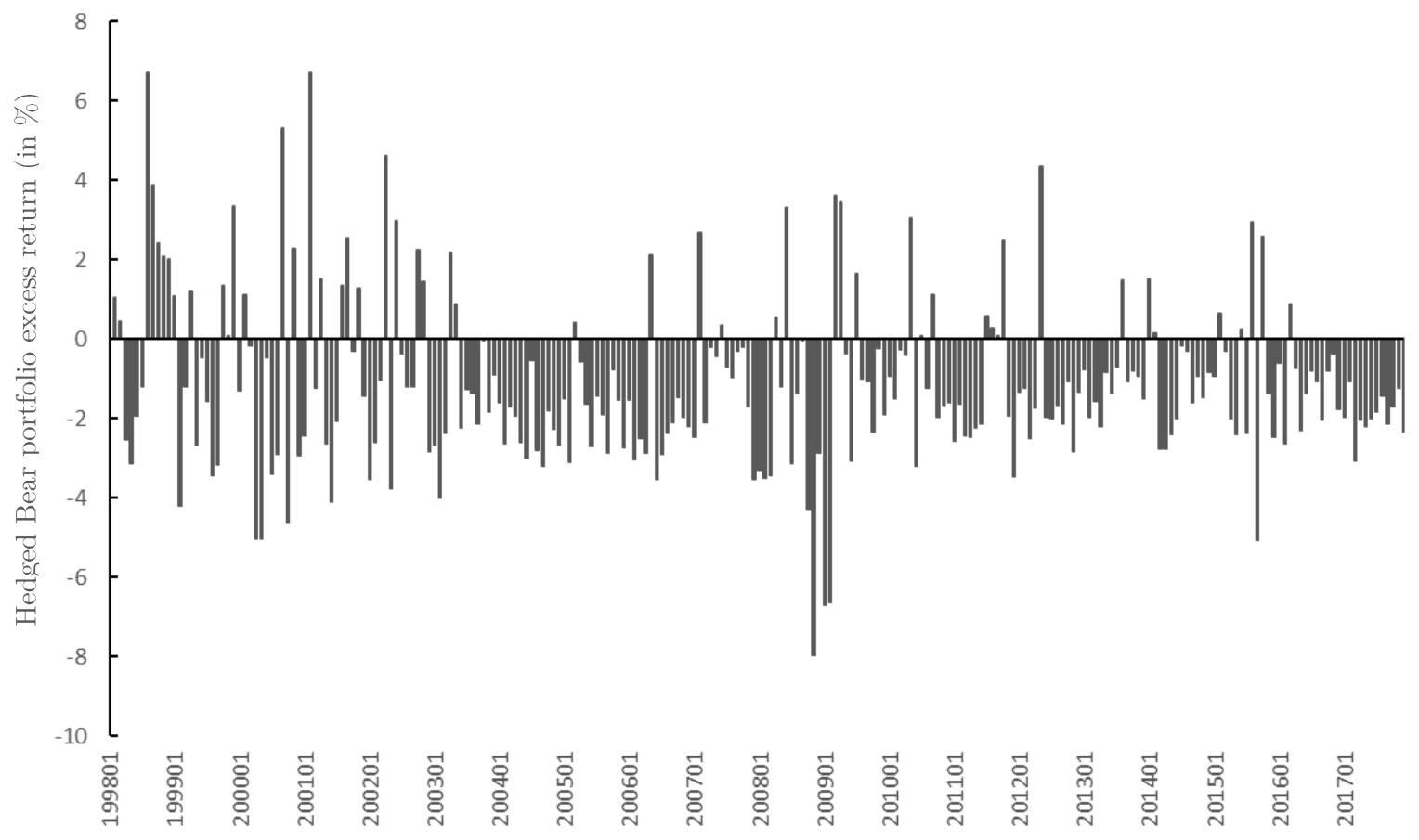


Table 1: Descriptive statistics of hedge funds

The table presents summary statistics for the hedge funds used in our sample. Panel A shows the time-series average of the monthly cross-sectional mean, standard deviation, and percentiles for the returns (in percent) of hedge funds in each investment style category and in total. $\mathrm{N}$ is the number of distinct hedge funds in each category. Panel B presents cross-sectional mean and distribution statistics for hedge fund characteristics including size, age, management fee, incentive fee, redemption notice period, lockup period, and minimum investment amount for all hedge funds in our sample. Our sample covers hedge funds from the HFR database over the period from January 1996 to December 2017.

Panel A: Summary statistics of hedge fund returns (in percent) by categories

\begin{tabular}{lcccccccc}
\hline & $\mathrm{N}$ & Mean & STD & P10 & P25 & P50 & P75 & P90 \\
\hline Event-Driven & 832 & 0.70 & 3.22 & -1.86 & -0.48 & 0.61 & 1.74 & 3.27 \\
Relative Value & 1366 & 0.62 & 2.74 & -1.54 & -0.26 & 0.64 & 1.56 & 2.84 \\
Long-Short Equity & 2936 & 0.78 & 4.73 & -3.93 & -1.46 & 0.70 & 2.91 & 5.51 \\
Global Macro & 443 & 0.64 & 4.39 & -3.71 & -1.31 & 0.54 & 2.47 & 5.08 \\
CTA & 422 & 0.45 & 4.20 & -3.67 & -1.30 & 0.33 & 2.05 & 4.64 \\
Equity Market-Neutral & 549 & 0.42 & 2.30 & -2.08 & -0.76 & 0.42 & 1.57 & 2.95 \\
Multi-Strategy & 1715 & 0.65 & 4.07 & -3.32 & -1.17 & 0.58 & 2.37 & 4.63 \\
Short-Bias & 60 & -0.15 & 3.55 & -4.50 & -2.45 & -0.19 & 2.11 & 4.30 \\
Sector & 505 & 0.97 & 5.20 & -4.56 & -1.74 & 0.90 & 3.48 & 6.56 \\
Fund of Funds & 2256 & 0.50 & 1.86 & -1.17 & -0.26 & 0.50 & 1.26 & 2.14 \\
\hline All hedge funds & 11084 & 0.64 & 4.03 & -2.93 & -0.83 & 0.55 & 2.01 & 4.24 \\
\hline
\end{tabular}

Panel B: Summary statistics of hedge fund characteristics

\begin{tabular}{lcccccccc}
\hline & $\mathrm{N}$ & Mean & STD & P10 & P25 & P50 & P75 & P90 \\
\hline Average monthly AUM (\$M) & 11084 & 175.22 & 604.65 & 14.20 & 23.59 & 52.31 & 140.33 & 370.31 \\
Average age (in months) & 11084 & 78.33 & 63.95 & 16.27 & 31.96 & 60.00 & 107.01 & 167.07 \\
Management fee (\%) & 11084 & 1.44 & 0.57 & 1.00 & 1.00 & 1.50 & 2.00 & 2.00 \\
Incentive fee (\%) & 11084 & 15.78 & 7.54 & 0.00 & 10.00 & 20.00 & 20.00 & 20.00 \\
Redemption (in months) & 11084 & 1.24 & 1.10 & 0.03 & 0.33 & 1.00 & 2.00 & 3.00 \\
Lock Up (in months) & 11084 & 3.46 & 6.92 & 0.00 & 0.00 & 0.00 & 6.00 & 12.00 \\
Minimum Investment (\$M) & 11084 & 1.26 & 4.63 & 0.05 & 0.10 & 0.50 & 1.00 & 2.00 \\
\hline
\end{tabular}


Table 2: Descriptive statistics for Bear portfolio and analysis of its returns

The table reports summary statistics and factor analysis for the Bear factor. Bear factor is the one-month buy-and-hold excess return of a bear spread portfolio that longs an OTM put and shorts a further OTM put on the S\&P 500 index. Panel A presents the mean (Mean), standard deviation (STD), skewness (Skew), minimum value (Min), $10^{\text {th }}$ percentile value $(\mathrm{P} 10), 50^{\text {th }}$ percentile value (P50), 90 ${ }^{\text {th }}$ percentile value (P90), and maximum value (Max) for the monthly time-series of the Bear factor (Bear) and the market factor (MKT) from January 1996 to December 2017. Panel B shows the result from the time-series regression of the Bear factor on the market factor over 264 months from January 1996 to December 2017. Panel C reports the summary statistics for the market-hedged Bear factor return (H-Bear) over January 1998 to December 2017, where H-Bear return in month $t$ is equal to the intercept coefficient plus the month $t$ residual from a regression of the Bear portfolio excess returns on the market excess returns over the past 24 months. Panel D shows the association between H-Bear and MKT in different market states. Newey and West (1987) t-statistics with lag length equal to 24 are reported in parentheses. ${ }^{*},{ }^{* *}$, and ${ }^{* * *}$ represent significance levels at $10 \%, 5 \%$, and $1 \%$.

Panel A: Summary statistics of the Bear portfolio excess returns (in percent)

\begin{tabular}{lcccccccc}
\hline Factor & Mean & STD & Skew & Min & P10 & P50 & P90 & Max \\
\hline Bear & -1.64 & 4.41 & 2.64 & -5.18 & -4.71 & -3.27 & 4.10 & 27.55 \\
MKT & 0.65 & 4.41 & -0.72 & -17.23 & -5.46 & 1.19 & 6.08 & 11.35 \\
\hline
\end{tabular}

Panel B: Analysis of the Bear portfolio excess returns

\begin{tabular}{lcc}
\hline & $(1)$ & $(2)$ \\
\hline Constant & $-1.64^{* * *}$ & $-1.09^{* * *}$ \\
& $(-5.04)$ & $(-6.77)$ \\
MKT & & $-0.85^{* * *}$ \\
& & $(-15.90)$ \\
\hline Adjusted $\mathrm{R}^{2}$ & 0.00 & 0.72 \\
\hline
\end{tabular}

Panel C: Summary statistics of the H-Bear return (in percent; based on 24-month rolling window)

\begin{tabular}{lcccccccc}
\hline Factor & Mean & STD & Skew & Min & P10 & P50 & P90 & Max \\
\hline H-Bear & -1.25 & 2.30 & 0.97 & -8.72 & -3.35 & -1.69 & 2.02 & 9.20 \\
\hline
\end{tabular}

Panel D: Relation between H-Bear factor return and market return in different market states

\begin{tabular}{lcc}
\hline & Average H-Bear & Average MKT \\
\hline MKT $<0$ & -1.41 & \\
MKT $>0$ & -1.16 & \\
5 largest market losses & -0.22 & 0.24 \\
H-Bear $<0$ & & 1.69 \\
H-Bear $>0$ & & \\
\hline
\end{tabular}


Table 3: H-Bear beta quintile portfolios and market exposure

The table reports the average H-Bear beta and market exposure based on different regression models for each H-Bear beta quintile portfolio. H-Bear beta $\left(\beta^{H-B E A R}\right)$ is estimated from a regression of hedge fund excess returns on the Bear factor controlling for the market excess returns over the past 24 months with a requirement of at least 18 months of non-missing fund returns. At the end of each month from December 1997 to November 2017, we sort hedge funds into quintiles according to their H-Bear betas. Quintile 1 (5) consists of funds with the lowest (highest) H-Bear betas. For each quintile, we report the time-series average of regression coefficients. In Panel A, $\beta^{M}$ is the coefficient $\beta_{i, t}^{M}$ from the regression of monthly hedge fund excess returns on the market excess returns and the Bear factor returns: $r_{i, t}=\alpha_{i, t}+\beta_{i, t}^{M} \times M K T_{t}+\beta_{i, t}^{H-B E A R} \times r_{B E A R, t}+\epsilon_{i, t}$ over the past 24 months. In Panel $\mathrm{B}, \beta^{M K T}$ and $\beta^{H-B E A R}$ are respectively the coefficients $\beta_{i, t}^{M K T}$ and $\beta_{i, t}^{H-B E A R}$ from the regression of monthly hedge fund excess returns on the market excess returns and markethedged Bear factor returns: $r_{i, t}=\alpha_{i, t}+\beta_{i, t}^{M K T} \times M K T_{t}+\beta_{i, t}^{H-B E A R} \times r_{H-B E A R, t}+\epsilon_{i, t}$ over the past 24 months, where the market-hedged Bear factor returns are estimated as residuals from the regression of the Bear factor returns on the market excess returns over the past 24 months. In Panel C, $\beta^{B E A R}$ is the coefficient $\beta_{i, t}^{B E A R}$ from the regression of monthly hedge fund excess returns on the Bear factor returns: $r_{i, t}=\alpha_{i, t}+$ $\beta_{i, t}^{B E A R} \times r_{B E A R, t}+\epsilon_{i, t}$ over the past 24 months. We also report the results for the Q5-Q1. Newey and West (1987) t-statistics with lag length equal to 24 are reported in parentheses. ${ }^{*},{ }^{* *}$, and ${ }^{* * *}$ represent significance levels at $10 \%, 5 \%$, and $1 \%$.

\begin{tabular}{lccccccc} 
Panel A: Regression model $r_{i, t}=\alpha_{i, t}+\beta_{i, t}^{M} \times M K T_{t}+\beta_{i, t}^{H-B E A R} \times r_{B E A R, t}+\epsilon_{i, t}$ \\
\hline Sort by $\beta^{H-B E A R}$ & $\mathrm{Q} 1$ & $\mathrm{Q} 2$ & $\mathrm{Q} 3$ & $\mathrm{Q} 4$ & $\mathrm{Q} 5$ & $\mathrm{Q} 5-\mathrm{Q} 1$ & t-stat $(\mathrm{Q} 5-\mathrm{Q} 1)$ \\
\hline$\beta^{M}$ & -0.04 & 0.15 & 0.22 & 0.36 & 0.89 & $0.93^{* * *}$ & $(10.54)$ \\
$\beta^{H-B E A R}$ & -0.55 & -0.14 & -0.03 & 0.10 & 0.53 & $1.08^{* * *}$ & $(13.55)$ \\
\hline
\end{tabular}

\begin{tabular}{|c|c|c|c|c|c|c|c|}
\hline Sort by $\beta^{H-B E A R}$ & Q1 & Q2 & Q3 & Q4 & Q5 & Q5-Q1 & t-stat (Q5-Q1) \\
\hline$\beta^{M K T}$ & 0.43 & 0.27 & 0.24 & 0.28 & 0.43 & 0.01 & $(0.10)$ \\
\hline$\beta^{H-B E A R}$ & -0.55 & -0.14 & -0.03 & 0.10 & 0.53 & $1.08^{* * *}$ & $(13.55)$ \\
\hline
\end{tabular}

\begin{tabular}{|c|c|c|c|c|c|c|c|}
\hline Sort by $\beta^{H-B E A R}$ & Q1 & Q2 & Q3 & Q4 & Q5 & Q5-Q1 & t-stat (Q5-Q1) \\
\hline$\beta^{B E A R}$ & -0.51 & -0.28 & -0.22 & -0.22 & -0.27 & $0.24^{* * *}$ & $(4.63)$ \\
\hline
\end{tabular}


Table 4: Performance of H-Bear beta-sorted hedge fund portfolios

The table reports the results from the analysis of H-Bear beta-sorted hedge fund portfolios. H-Bear beta $\left(\beta^{H-B E A R}\right)$ is estimated from a regression of hedge fund excess returns on the Bear factor controlling for the market excess returns over the past 24 months with a requirement of at least 18 months of non-missing fund returns. Panel A presents the average returns and Fung-Hsieh alphas (in monthly percentages) of hedge fund portfolios sorted with respect to H-Bear beta. At the end of each month from December 1997 to November 2017, we sort hedge funds into quintiles according to their H-Bear beta level. Quintile 1 (5) consists of funds with the lowest (highest) H-Bear betas. We hold these quintile portfolios for one month and present the average equal-weighted returns and alphas for each quintile and for the Q5-Q1 portfolio. Panel B presents alphas (or intercept coefficients) and slope coefficients from time-series regressions of the monthly equalweighted Q5-Q1 H-Bear beta portfolio returns on different risk factors. As standard risk factors, we use the seven factors from the Fung and Hsieh (2004) model, which include three trend-following risk factors (PTFSBD, PTFSFX, PTFSCOM), two equity-oriented risk factors (S\&P, SCMLC), and two bond-oriented risk factors (BD10RET, BAAMTSY). In addition to the Fung and Hsieh (2004) seven factors, we use the Fama and French (1993) value factor (HML), the Carhart (1997) momentum factor (UMD), the Pastor and Stambaugh (2003) liquidity factor (PS LIQ), and returns of a long-short hedge fund portfolio with regard to the Bali, Brown, and Caglayan (2014) macroeconomic uncertainty factor (Return Macro), the Agarwal, Bakshi, and Huij (2010) relative change in risk-neutral volatility and skewness (Return VOL and Return SKEW), the Gao, Gao, and Song (2018) RIX factor (Return RIX), and the Agarwal, Ruenzi, and Weigert (2017) tail risk factor (Return TailRisk). Newey and West (1987) t-statistics with lag length equal to 24 are reported in parentheses. ${ }^{*},{ }^{* *}$, and ${ }^{* * *}$ represent significance levels at $10 \%, 5 \%$, and $1 \%$.

Panel A: Univariate portfolio sorts

\begin{tabular}{lcccccc}
\hline & Q1 & Q2 & Q3 & Q4 & Q5 & Q5-Q1 \\
\hline Equal-weighted returns (\%) & 0.87 & 0.56 & 0.47 & 0.44 & 0.29 & $-0.58^{* * *}$ \\
& $(5.44)$ & $(5.00)$ & $(3.93)$ & $(3.27)$ & $(1.61)$ & $(-3.53)$ \\
FH alpha & 0.70 & 0.40 & 0.30 & 0.23 & -0.02 & $-0.72^{* * *}$ \\
& $(4.04)$ & $(3.94)$ & $(3.21)$ & $(2.38)$ & $(-0.17)$ & $(-3.73)$ \\
\hline
\end{tabular}


Panel B: Alphas after controlling additional factors

\begin{tabular}{|c|c|c|c|c|c|c|c|c|}
\hline & $\begin{array}{c}(1) \\
\mathrm{Q} 5-\mathrm{Q} 1\end{array}$ & $\begin{array}{c}(2) \\
\mathrm{Q} 5-\mathrm{Q} 1\end{array}$ & $\begin{array}{c}(3) \\
\mathrm{Q} 5-\mathrm{Q} 1\end{array}$ & $\begin{array}{c}(4) \\
\mathrm{Q} 5-\mathrm{Q} 1\end{array}$ & $\begin{array}{c}(5) \\
\text { Q5-Q1 }\end{array}$ & $\begin{array}{c}(6) \\
\text { Q5-Q1 }\end{array}$ & $\begin{array}{c}(7) \\
\mathrm{Q} 5-\mathrm{Q} 1\end{array}$ & $\begin{array}{c}(8) \\
\text { Q5-Q1 }\end{array}$ \\
\hline Alpha & $\begin{array}{c}-0.72^{* * *} \\
(-3.73)\end{array}$ & $\begin{array}{c}-0.69^{* * *} \\
(-3.34)\end{array}$ & $\begin{array}{c}-0.67^{* * *} \\
(-2.93)\end{array}$ & $\begin{array}{c}-0.59^{* * *} \\
(-4.04)\end{array}$ & $\begin{array}{c}-0.57^{* * *} \\
(-3.63)\end{array}$ & $\begin{array}{c}-0.61^{* * *} \\
(-3.12)\end{array}$ & $\begin{array}{c}-0.71^{* * *} \\
(-3.57)\end{array}$ & $\begin{array}{c}-0.49 * * * \\
(-3.38)\end{array}$ \\
\hline PTFSBD & $\begin{array}{c}-0.02 \\
(-1.00)\end{array}$ & $\begin{array}{l}-0.02 \\
(-1.20)\end{array}$ & $\begin{array}{c}-0.02 \\
(-1.24)\end{array}$ & $\begin{array}{l}-0.03 \\
(-1.62)\end{array}$ & $\begin{array}{l}-0.03 \\
(-1.64)\end{array}$ & $\begin{array}{l}-0.02 \\
(-1.03)\end{array}$ & $\begin{array}{l}-0.02 \\
(-1.37)\end{array}$ & $\begin{array}{l}-0.03^{*} \\
(-1.85)\end{array}$ \\
\hline PTFSFX & $\begin{array}{c}0.00 \\
(-0.29)\end{array}$ & $\begin{array}{c}0.00 \\
(-0.08)\end{array}$ & $\begin{array}{c}0.00 \\
(-0.05)\end{array}$ & $\begin{array}{c}0.00 \\
(-0.16)\end{array}$ & $\begin{array}{c}0.00 \\
(-0.19)\end{array}$ & $\begin{array}{c}0.00 \\
(0.11)\end{array}$ & $\begin{array}{c}0.00 \\
(-0.24)\end{array}$ & $\begin{array}{c}0.00 \\
(-0.20)\end{array}$ \\
\hline PTFSCOM & $\begin{array}{c}0.01 \\
(1.15)\end{array}$ & $\begin{array}{c}0.01 \\
(1.00)\end{array}$ & $\begin{array}{c}0.01 \\
(1.01)\end{array}$ & $\begin{array}{c}0.01 \\
(0.90)\end{array}$ & $\begin{array}{c}0.00 \\
(0.34)\end{array}$ & $\begin{array}{c}0.01 \\
(1.10)\end{array}$ & $\begin{array}{c}0.01 \\
(0.53)\end{array}$ & $\begin{array}{c}0.00 \\
(0.05)\end{array}$ \\
\hline $\mathrm{S} \& \mathrm{P}$ & $\begin{array}{c}0.13 \\
(1.51)\end{array}$ & $\begin{array}{c}0.11 \\
(1.41)\end{array}$ & $\begin{array}{c}0.11 \\
(1.34)\end{array}$ & $\begin{array}{c}0.11 \\
(1.53)\end{array}$ & $\begin{array}{c}0.08 \\
(1.48)\end{array}$ & $\begin{array}{c}0.09 \\
(1.01)\end{array}$ & $\begin{array}{c}0.27 \\
(1.52)\end{array}$ & $\begin{array}{c}0.19 \\
(1.51)\end{array}$ \\
\hline SCMLC & $\begin{array}{c}0.12 \\
(1.55)\end{array}$ & $\begin{array}{l}0.12^{*} \\
(1.94)\end{array}$ & $\begin{array}{c}0.12^{* *} \\
(2.00)\end{array}$ & $\begin{array}{c}0.14^{* *} \\
(2.12)\end{array}$ & $\begin{array}{c}0.03 \\
(0.84)\end{array}$ & $\begin{array}{c}0.13^{* *} \\
(2.28)\end{array}$ & $\begin{array}{l}0.18^{*} \\
(1.86)\end{array}$ & $\begin{array}{c}0.10^{* *} \\
(2.14)\end{array}$ \\
\hline BD10RET & $\begin{array}{c}0.00 \\
(0.70)\end{array}$ & $\begin{array}{c}0.00 \\
(0.83)\end{array}$ & $\begin{array}{c}0.00 \\
(0.82)\end{array}$ & $\begin{array}{l}0.01^{*} \\
(1.68)\end{array}$ & $\begin{array}{c}0.00 \\
(-0.08)\end{array}$ & $\begin{array}{c}0.01 \\
(1.27)\end{array}$ & $\begin{array}{c}0.00 \\
(0.68)\end{array}$ & $\begin{array}{c}0.00 \\
(0.52)\end{array}$ \\
\hline BAAMTSY & $\begin{array}{c}0.00 \\
(0.40)\end{array}$ & $\begin{array}{c}0.00 \\
(0.43)\end{array}$ & $\begin{array}{c}0.01 \\
(0.52)\end{array}$ & $\begin{array}{c}0.01 \\
(0.88)\end{array}$ & $\begin{array}{c}0.00 \\
(-0.16)\end{array}$ & $\begin{array}{l}0.01^{*} \\
(1.87)\end{array}$ & $\begin{array}{l}-0.01 \\
(-0.80)\end{array}$ & $\begin{array}{c}0.00 \\
(-0.26)\end{array}$ \\
\hline HML & & $\begin{array}{c}-0.16^{* * *} \\
(-3.20)\end{array}$ & $\begin{array}{c}-0.16^{* * *} \\
(-3.32)\end{array}$ & $\begin{array}{c}-0.14^{* *} \\
(-2.46)\end{array}$ & $\begin{array}{l}-0.05^{*} \\
(-1.62)\end{array}$ & $\begin{array}{c}-0.16^{* * *} \\
(-2.85)\end{array}$ & $\begin{array}{c}-0.25^{* *} \\
(-2.23)\end{array}$ & $\begin{array}{c}-0.11^{* *} \\
(-2.09)\end{array}$ \\
\hline UMD & & $\begin{array}{l}-0.01 \\
(-0.25)\end{array}$ & $\begin{array}{c}-0.01 \\
(-0.30)\end{array}$ & $\begin{array}{c}0.01 \\
(0.17)\end{array}$ & $\begin{array}{l}-0.02 \\
(-0.51)\end{array}$ & $\begin{array}{l}-0.01 \\
(-0.28)\end{array}$ & $\begin{array}{l}-0.03 \\
(-0.74)\end{array}$ & $\begin{array}{c}-0.03 \\
(-0.73)\end{array}$ \\
\hline PS LIQ & & & $\begin{array}{c}0.01 \\
(0.40)\end{array}$ & & & & & $\begin{array}{c}(0.00 \\
(-0.08)\end{array}$ \\
\hline Return Macro & & & & $\begin{array}{c}-0.19^{* * *} \\
(-2.91)\end{array}$ & & & & $\begin{array}{c}-0.09 \\
(-1.33)\end{array}$ \\
\hline Return VOL & & & & & $\begin{array}{c}0.50^{* * *} \\
(3.16)\end{array}$ & & & $\begin{array}{c}0.44^{* * *} \\
(2.90)\end{array}$ \\
\hline Return SKEW & & & & & $\begin{array}{c}0.31^{* * *} \\
(3.25)\end{array}$ & & & $\begin{array}{c}0.27^{* *} \\
(2.38)\end{array}$ \\
\hline Return RIX & & & & & & $\begin{array}{l}-0.23 \\
(-1.47)\end{array}$ & & $\begin{array}{c}-0.17 \\
(-1.15)\end{array}$ \\
\hline Return TailRisk & & & & & & & $\begin{array}{l}-0.26 \\
(-1.22)\end{array}$ & $\begin{array}{l}-0.20^{*} \\
(-1.87)\end{array}$ \\
\hline Adjusted $\mathrm{R}^{2}$ & 0.12 & 0.17 & 0.17 & 0.25 & 0.41 & 0.20 & 0.22 & 0.47 \\
\hline Observations & 240 & 240 & 240 & 240 & 240 & 240 & 240 & 240 \\
\hline
\end{tabular}


Table 5: Fama and MacBeth regressions

The table presents the average intercepts, average coefficients, and average adjusted $\mathrm{R}^{2} \mathrm{~S}$ from Fama and MacBeth (1973) cross-sectional regressions of hedge fund excess returns in month $t+1$ on H-Bear beta $\left(\beta^{H-B E A R}\right)$ and other control variables measured at the end of month $t$ over the sample period from January 1998 to December 2017. H-Bear beta is estimated from a regression of hedge fund excess returns on the Bear factor controlling for the market excess returns over the past 24 months with a requirement of at least 18 months of non-missing fund returns. The control variables include different fund characteristics, manager skill measure, and other measures of risks. A detailed definition of these variables is provided in Appendix A. Newey and West (1987) t-statistics with lag length equal to 24 are reported in parentheses. *, **, and *** represent significance levels at $10 \%, 5 \%$, and $1 \%$.

\begin{tabular}{|c|c|c|c|c|c|c|c|}
\hline Specification & (1) & $(2)$ & $(3)$ & (4) & $(5)$ & $(6)$ & (7) \\
\hline \multirow[t]{2}{*}{ Intercept } & $0.53^{* * *}$ & 0.20 & $0.18^{*}$ & 0.19 & $0.20^{*}$ & 0.10 & 0.12 \\
\hline & $(4.42)$ & $(1.64)$ & (1.68) & $(1.61)$ & $(1.78)$ & $(0.72)$ & $(1.12)$ \\
\hline \multirow[t]{2}{*}{$\beta^{H-B E A R}$} & $-0.59^{* * *}$ & $-0.35^{* * *}$ & $-0.25^{* * *}$ & $-0.29^{* * *}$ & $-0.33^{* * *}$ & $-0.22^{* * *}$ & $-0.29^{* * *}$ \\
\hline & $(-3.63)$ & $(-3.72)$ & $(-3.24)$ & $(-3.30)$ & $(-3.33)$ & $(-3.79)$ & $(-3.05)$ \\
\hline \multirow[t]{2}{*}{ Size } & & -0.02 & -0.01 & -0.02 & -0.01 & -0.01 & 0.00 \\
\hline & & $(-1.23)$ & $(-1.01)$ & $(-1.21)$ & $(-1.08)$ & $(-0.86)$ & $(-0.39)$ \\
\hline \multirow[t]{2}{*}{ Age } & & 0.00 & 0.00 & 0.00 & 0.00 & 0.00 & 0.00 \\
\hline & & $(-0.20)$ & $(-0.18)$ & $(-0.33)$ & $(0.38)$ & $(-0.42)$ & $(0.06)$ \\
\hline \multirow[t]{2}{*}{ Min Investment } & & $0.01^{* * *}$ & $0.01^{* * *}$ & $0.01^{* * *}$ & $0.01^{* * *}$ & $0.01^{* *}$ & $0.01^{* *}$ \\
\hline & & $(2.82)$ & $(2.69)$ & $(2.88)$ & $(2.89)$ & $(2.46)$ & $(2.14)$ \\
\hline \multirow[t]{2}{*}{ Management Fee } & & -0.02 & -0.01 & -0.02 & -0.01 & -0.02 & -0.01 \\
\hline & & $(-0.70)$ & $(-0.39)$ & $(-0.91)$ & $(-0.42)$ & $(-0.88)$ & $(-0.30)$ \\
\hline \multirow[t]{2}{*}{ Incentive Fee } & & 0.00 & 0.00 & $0.00^{*}$ & $0.00^{*}$ & 0.00 & 0.00 \\
\hline & & $(1.41)$ & $(1.35)$ & $(1.65)$ & $(1.70)$ & $(1.26)$ & (1.38) \\
\hline \multirow[t]{2}{*}{ Lock Up } & & 0.00 & 0.00 & 0.00 & 0.00 & 0.00 & 0.00 \\
\hline & & $(0.75)$ & $(0.32)$ & $(0.95)$ & $(0.39)$ & $(0.66)$ & $(0.07)$ \\
\hline \multirow[t]{2}{*}{ Redemption } & & 0.01 & 0.01 & 0.02 & 0.02 & 0.01 & 0.01 \\
\hline & & $(0.54)$ & $(0.42)$ & $(0.76)$ & $(0.64)$ & $(0.29)$ & $(0.62)$ \\
\hline \multirow[t]{2}{*}{ Leverage } & & -0.03 & -0.02 & $-0.04^{*}$ & $-0.04^{*}$ & -0.02 & -0.03 \\
\hline & & $(-1.46)$ & $(-1.16)$ & $(-1.67)$ & $(-1.72)$ & $(-1.34)$ & $(-1.60)$ \\
\hline \multirow{2}{*}{ Hurdle } & & -0.06 & -0.06 & -0.06 & -0.06 & -0.06 & -0.05 \\
\hline & & $(-1.43)$ & $(-1.63)$ & $(-1.46)$ & $(-1.47)$ & $(-1.38)$ & $(-1.40)$ \\
\hline \multirow[t]{2}{*}{ HWM } & & 0.00 & 0.01 & 0.00 & -0.01 & 0.01 & 0.00 \\
\hline & & $(-0.14)$ & $(0.24)$ & $(-0.21)$ & $(-0.66)$ & $(0.33)$ & $(-0.10)$ \\
\hline \multirow[t]{2}{*}{ Offshore } & & -0.02 & -0.01 & -0.02 & -0.03 & -0.01 & -0.02 \\
\hline & & $(-0.76)$ & $(-0.39)$ & $(-0.80)$ & $(-1.09)$ & $(-0.42)$ & $(-0.66)$ \\
\hline \multirow[t]{2}{*}{ Past return (12M) } & & $1.62^{* * *}$ & $1.73^{* * *}$ & $1.63^{* * *}$ & $1.59^{* * *}$ & $1.84^{* * *}$ & $1.80^{* * *}$ \\
\hline & & $(5.68)$ & $(7.33)$ & $(5.30)$ & $(6.67)$ & $(7.36)$ & $(6.20)$ \\
\hline \multirow[t]{2}{*}{ Ret VOL $(24 \mathrm{M})$} & & $4.04^{*}$ & $3.11^{*}$ & $4.37^{*}$ & $3.96^{* *}$ & $3.15^{*}$ & $3.71^{* * *}$ \\
\hline & & $(1.65)$ & (1.87) & $(1.93)$ & $(2.06)$ & $(1.94)$ & $(2.69)$ \\
\hline \multirow[t]{2}{*}{ Ret SKEW (24M) } & & 0.03 & $0.05^{* *}$ & 0.02 & 0.04 & $0.05^{* *}$ & $0.04^{*}$ \\
\hline & & $(0.92)$ & $(2.03)$ & $(0.68)$ & $(1.22)$ & $(2.20)$ & $(1.89)$ \\
\hline Ret KURT (24M) & & 0.00 & 0.00 & -0.01 & 0.00 & 0.00 & 0.00 \\
\hline
\end{tabular}


Table 6: H-Bear beta effect during market crashes versus normal times

The table shows results from Fama and Macbeth (1973) cross-sectional regressions of one-month ahead hedge fund excess returns on H-Bear beta $\left(\beta^{H-B E A R}\right)$ and a series of control variables in different subperiods. The control variables included are the same with Specification (7) of Table 5. H-Bear beta is estimated from a regression of hedge fund excess returns on the Bear factor controlling for the market excess returns over the past 24 months with a requirement of at least 18 months of non-missing fund returns. We present only the coefficients on H-Bear beta $\left(\beta^{H-B E A R}\right)$ and market beta $\left(\beta^{M K T}\right)$; the coefficients for the rest of the variables are suppressed for the sake of brevity. MKT denotes the excess return of the market. Newey and West (1987) t-statistics with lag length equal to 24 are reported in parentheses. ${ }^{*}, * *$, and ${ }^{* * *}$ represent significance levels at $10 \%, 5 \%$, and $1 \%$.

\begin{tabular}{lcccc}
\hline MODEL & $(1)$ & $(2)$ & $(3)$ & $(4)$ \\
& MKT $<$ P10 & MKT $>$ P10 & MKT $<0$ & MKT $>0$ \\
\hline$\beta^{H-B E A R}$ & $-1.15^{* * *}$ & $-0.20^{*}$ & $-0.67^{* * *}$ & -0.06 \\
& $(-2.75)$ & $(-1.83)$ & $(-2.62)$ & $(-0.42)$ \\
$\beta^{M K T}$ & $-6.83^{* * *}$ & $1.13^{* * *}$ & $-2.61^{* * *}$ & $2.13^{* * *}$ \\
& $(-10.96)$ & $(5.35)$ & $(-7.40)$ & $(6.21)$ \\
Control variables & Yes & Yes & Yes & Yes \\
Average adjusted $\mathrm{R}^{2}$ & 0.43 & 0.27 & 0.30 & 0.28 \\
Number of months & 24 & 216 & 91 & 149 \\
\hline
\end{tabular}


Table 7: H-Bear beta effect when bear market risk is (not) realized

The table shows results from Fama and Macbeth (1973) cross-sectional regressions of one-month ahead hedge fund excess returns on H-Bear beta $\left(\beta^{H-B E A R}\right)$ and a series of control variables when bear market risk is realized versus when it is not realized. We define realized (unrealized) bear market risk periods as months with positive (negative) H-Bear factor returns. H-Bear factor is the component of the Bear factor that is orthogonal to the market excess returns. In month $t$, H-Bear return is equal to the intercept coefficient plus the month $t$ residual from a regression of the Bear factor on the market excess returns over the past 24 months. The control variables included are the same with Specification (7) of Table 5. We present only the coefficients on H-Bear beta $\left(\beta^{H-B E A R}\right)$ and market beta $\left(\beta^{M K T}\right)$; the coefficients on other control variables are suppressed for the sake of brevity. Newey and West (1987) t-statistics with lag length equal to 24 are reported in parentheses. ${ }^{*}, * *$, and ${ }^{* * *}$ represent significance levels at $10 \%, 5 \%$, and $1 \%$.

\begin{tabular}{lcc}
\hline MODEL & $(1)$ & $(2)$ \\
& H-Bear factor $<0$ & H-Bear factor $>0$ \\
\hline$\beta^{H-B E A R}$ & $-0.49^{* * *}$ & $0.44^{* * *}$ \\
& $(-3.50)$ & $(3.16)$ \\
$\beta^{M K T}$ & 0.04 & $1.41^{* * *}$ \\
& $(0.15)$ & $(4.41)$ \\
Control variables & Yes & Yes \\
Average adjusted $\mathrm{R}^{2}$ & 0.26 & 0.38 \\
Number of months & 189 & 51 \\
\hline
\end{tabular}


Table 8: Determinants of H-Bear betas

The table presents the average intercepts, average coefficients, and average adjusted $\mathrm{R}^{2} \mathrm{~S}$ from Fama and MacBeth (1973) cross-sectional regressions of hedge fund H-Bear beta $\left(\beta^{H-B E A R}\right)$ on contemporaneous fund characteristics and risk attributes over the period from December 1997 to November 2017. H-Bear beta is estimated from a regression of hedge fund excess returns on the Bear factor controlling for the market excess returns over the past 24 months with a requirement of at least 18 months of non-missing fund returns. A detailed definition of different fund characteristics and other measures of risks is provided in Appendix A. Newey and West (1987) t-statistics with lag length equal to 24 are reported in parentheses. ${ }^{*}$, **, and *** represent significance levels at $10 \%, 5 \%$, and $1 \%$.

\begin{tabular}{|c|c|c|c|}
\hline Specification & $(1)$ & $(2)$ & $(3)$ \\
\hline \multirow[t]{2}{*}{ Intercept } & 0.00 & -0.03 & 0.00 \\
\hline & $(0.01)$ & $(-0.63)$ & $(-0.15)$ \\
\hline \multirow[t]{2}{*}{ Size } & 0.00 & & 0.00 \\
\hline & $(1.18)$ & & $(0.83)$ \\
\hline \multirow[t]{2}{*}{ Age } & $0.00^{*}$ & & $0.00^{*}$ \\
\hline & $(1.82)$ & & $(1.90)$ \\
\hline \multirow[t]{2}{*}{ Ret VOL $(24 \mathrm{M})$} & 0.07 & & -0.16 \\
\hline & $(0.18)$ & & $(-0.29)$ \\
\hline \multirow[t]{2}{*}{ Ret SKEW (24M) } & $0.10^{* * *}$ & & $0.09^{* * *}$ \\
\hline & $(6.00)$ & & $(5.89)$ \\
\hline \multirow[t]{2}{*}{ Ret KURT (24M) } & 0.00 & & 0.00 \\
\hline & $(-1.51)$ & & $(-1.56)$ \\
\hline \multirow[t]{2}{*}{ Fund return $(12 \mathrm{M})$} & $-0.29^{* *}$ & & $-0.27^{* *}$ \\
\hline & $(-2.15)$ & & $(-2.30)$ \\
\hline \multirow[t]{2}{*}{ Min Investment } & & 0.00 & 0.00 \\
\hline & & $(1.19)$ & $(1.47)$ \\
\hline \multirow[t]{2}{*}{ Management Fee } & & $-0.02^{* *}$ & $-0.02^{* *}$ \\
\hline & & $(-1.97)$ & $(-2.24)$ \\
\hline \multirow[t]{2}{*}{ Incentive Fee } & & $0.00^{*}$ & 0.00 \\
\hline & & $(1.85)$ & $(1.05)$ \\
\hline \multirow[t]{2}{*}{ Lock Up } & & 0.00 & 0.00 \\
\hline & & $(0.38)$ & $(0.84)$ \\
\hline \multirow[t]{2}{*}{ Redemption } & & -0.01 & 0.00 \\
\hline & & $(-1.48)$ & $(-0.32)$ \\
\hline \multirow[t]{2}{*}{ Leverage } & & $0.01^{* *}$ & $0.01^{*}$ \\
\hline & & $(2.15)$ & $(1.68)$ \\
\hline \multirow[t]{2}{*}{ Hurdle } & & $-0.04^{* * *}$ & $-0.02^{* *}$ \\
\hline & & $(-2.73)$ & $(-1.98)$ \\
\hline \multirow[t]{2}{*}{ HWM } & & 0.01 & 0.01 \\
\hline & & (1.08) & (1.17) \\
\hline \multirow[t]{2}{*}{ Offshore } & & $-0.04^{* * *}$ & $-0.03^{* * *}$ \\
\hline & & $(-2.73)$ & $(-3.05)$ \\
\hline Adjusted $\mathrm{R}^{2}$ & 0.14 & 0.03 & 0.16 \\
\hline
\end{tabular}


Table 9: Long-term predictive power of H-Bear factor exposure

The table reports the long-term performance of H-Bear beta-sorted hedge fund quintle portfolios. All portfolios are equal-weighted. In Panel A, we report the time-series average of $k$ th-month ahead excess returns for each of the hedge fund quintiles formed each month on the basis of H-Bear beta as well as the average $k$ th-month ahead return and Fung-Hsieh alpha differences between the high and low H-Bear beta quintiles (Q5-Q1). Panel B presents results for the H-Bear beta-sorted quintile portfolios with holding periods ranging from 3 months to 24 months. We implement the independently managed portfolio strategy of Jegadeesh and Titman (1993) to deal with the overlapping nature of the long-horizon returns and compute average monthly excess returns. We report the monthly average returns for each quintile as well as the average return and Fung-Hsieh alpha differences for the Q5-Q1 portfolio. In Panel C, we perform the same analysis as in Panel B except that we leave a one-month gap between the portfolio formation month and the month in which portfolio returns start being calculated. Newey and West (1987) t-statistics with lag length equal to 24 are reported in parentheses. ${ }^{*},{ }^{* *}$, and ${ }^{* * *}$ represent significance levels at $10 \%, 5 \%$, and $1 \%$.

\begin{tabular}{|c|c|c|c|c|c|c|c|c|}
\hline$t+k$ month ahead returns & $t+2$ & $t+3$ & $t+4$ & $t+5$ & $t+6$ & $t+7$ & $t+8$ & $t+9$ \\
\hline Q1 (Low $\left.\beta^{H-B E A R}\right)$ & 0.89 & 0.84 & 0.77 & 0.77 & 0.77 & 0.74 & 0.71 & 0.69 \\
\hline Q2 & 0.57 & 0.56 & 0.54 & 0.53 & 0.52 & 0.50 & 0.49 & 0.54 \\
\hline Q3 & 0.48 & 0.47 & 0.47 & 0.44 & 0.46 & 0.46 & 0.46 & 0.48 \\
\hline Q4 & 0.41 & 0.41 & 0.41 & 0.42 & 0.42 & 0.45 & 0.45 & 0.49 \\
\hline Q5 (High $\left.\beta^{H-B E A R}\right)$ & 0.29 & 0.32 & 0.35 & 0.39 & 0.42 & 0.45 & 0.52 & 0.56 \\
\hline \multirow[t]{2}{*}{ Q5-Q1 } & $-0.60^{* * *}$ & $-0.53^{* * *}$ & $-0.42^{* * *}$ & $-0.38^{* * *}$ & $-0.34^{* * *}$ & $-0.29^{* * *}$ & $-0.19^{*}$ & -0.13 \\
\hline & $(-3.57)$ & $(-3.45)$ & $(-3.61)$ & $(-3.72)$ & $(-4.02)$ & $(-3.19)$ & $(-1.91)$ & $(-1.03)$ \\
\hline \multirow[t]{2}{*}{ FH alpha } & $-0.75^{* * *}$ & $-0.65^{* * *}$ & $-0.49^{* * *}$ & $-0.46^{* * *}$ & $-0.41^{* * *}$ & $-0.37^{* * *}$ & $-0.28^{* *}$ & $-0.20^{*}$ \\
\hline & $(-3.69)$ & $(-3.61)$ & $(-4.05)$ & $(-3.73)$ & $(-4.44)$ & $(-2.97)$ & $(-2.56)$ & $(-1.67)$ \\
\hline
\end{tabular}


Panel B: Predictive power of H-Bear beta for long-term holding period returns

\begin{tabular}{lcccccccc}
\hline Holding for the next & 3 months & 6 months & 9 months & 12 months & 15 months & 18 months & 21 months & 24 months \\
\hline Q1 (Low $\beta^{H-B E A R}$ ) & 0.87 & 0.83 & 0.80 & 0.76 & 0.74 & 0.70 & 0.67 \\
Q2 & 0.56 & 0.55 & 0.56 & 0.55 & 0.54 & 0.52 & 0.52 & 0.54 \\
Q3 & 0.47 & 0.46 & 0.49 & 0.48 & 0.48 & 0.46 & 0.45 \\
Q4 & 0.41 & 0.41 & 0.47 & 0.47 & 0.46 & 0.44 & 0.43 & 0.44 \\
Q5 (High $\beta^{H-B E A R}$ ) & 0.29 & 0.35 & 0.46 & 0.46 & 0.48 & 0.46 & 0.46 & 0.46 \\
\hline Q5-Q1 & $-0.58^{* * *}$ & $-0.49^{* * *}$ & $-0.34^{* * *}$ & $-0.30^{* * *}$ & $-0.27^{* * *}$ & $-0.23^{* * *}$ & $-0.21^{* * *}$ & $-0.18^{* *}$ \\
& $(-3.53)$ & $(-3.79)$ & $(-2.99)$ & $(-3.18)$ & $(-3.28)$ & $(-2.97)$ & $(-2.63)$ & $(-2.30)$ \\
FH alpha & $-0.71^{* * *}$ & $-0.58^{* * *}$ & $-0.39^{* * *}$ & $-0.34^{* * *}$ & $-0.29^{* * *}$ & $-0.25^{* *}$ & $-0.23^{* *}$ & $-0.19^{*}$ \\
& $(-3.66)$ & $(-3.89)$ & $(-3.15)$ & $(-3.05)$ & $(-2.65)$ & $(-2.35)$ & $(-2.14)$ & $(-1.88)$ \\
\hline
\end{tabular}

Panel C: Long-term holding period with a 1-month lag between ranking and performance months

\begin{tabular}{|c|c|c|c|c|c|c|c|c|}
\hline $\begin{array}{l}\text { 1-month lag and holding } \\
\text { for the next }\end{array}$ & 3 months & 6 months & 9 months & 12 months & 15 months & 18 months & 21 months & 24 months \\
\hline Q1 (Low $\left.\beta^{H-B E A R}\right)$ & 0.84 & 0.79 & 0.75 & 0.72 & 0.70 & 0.68 & 0.66 & 0.64 \\
\hline Q2 & 0.57 & 0.55 & 0.54 & 0.54 & 0.53 & 0.53 & 0.53 & 0.52 \\
\hline Q3 & 0.48 & 0.47 & 0.47 & 0.47 & 0.47 & 0.47 & 0.47 & 0.48 \\
\hline Q4 & 0.42 & 0.43 & 0.44 & 0.44 & 0.44 & 0.45 & 0.45 & 0.46 \\
\hline Q5 $\left(\operatorname{High} \beta^{H-B E A R}\right)$ & 0.34 & 0.39 & 0.43 & 0.46 & 0.48 & 0.50 & 0.51 & 0.53 \\
\hline Q5-Q1 & $\begin{array}{c}-0.50^{* * *} \\
(-3.55)\end{array}$ & $\begin{array}{c}-0.40^{* * *} \\
(-3.66)\end{array}$ & $\begin{array}{c}-0.32^{* * *} \\
(-3.35)\end{array}$ & $\begin{array}{c}-0.26^{* * *} \\
(-2.97)\end{array}$ & $\begin{array}{c}-0.22^{* * *} \\
(-2.64)\end{array}$ & $\begin{array}{l}-0.18^{* *} \\
(-2.20)\end{array}$ & $\begin{array}{l}-0.15^{*} \\
(-1.75)\end{array}$ & $\begin{array}{c}-0.11 \\
(-1.28)\end{array}$ \\
\hline FH alpha & $\begin{array}{c}-0.62^{* * *} \\
(-3.82) \\
\end{array}$ & $\begin{array}{l}-0.51^{* * *} \\
(-3.98)\end{array}$ & $\begin{array}{c}-0.42^{* * *} \\
(-3.87)\end{array}$ & $\begin{array}{c}-0.36^{* * *} \\
(-3.47) \\
\end{array}$ & $\begin{array}{c}-0.31^{* * *} \\
(-3.08) \\
\end{array}$ & $\begin{array}{c}-0.28^{* * *} \\
(-2.77)\end{array}$ & $\begin{array}{l}-0.25 * * \\
(-2.41)\end{array}$ & $\begin{array}{l}-0.21^{* *} \\
(-2.02)\end{array}$ \\
\hline
\end{tabular}


Table 10: Performance of H-Bear beta-sorted hedge fund portfolios in different investment style categories The table reports the performance of H-Bear beta-sorted hedge fund portfolios for each investment style. HBear beta is estimated from a regression of hedge fund excess returns on the Bear factor controlling for the market excess returns over the past 24 months with a requirement of at least 18 months of non-missing fund returns. At the end of each month from December 1997 to November 2017, hedge funds of a specific investment style are sorted into five portfolios on the basis of their H-Bear betas. Quintile 1 (5) consists of funds with the lowest (highest) H-Bear betas. We rebalance the portfolios each month; thus, the portfolio returns are from January 1998 to December 2017. For each style, we present the average H-Bear beta, the average equalweighted return and Fung-Hsieh alpha (in percentage terms) for each quintile as well as for the Q5-Q1 portfolio. Newey and West (1987) t-statistics with lag length equal to 24 are reported in parentheses. ${ }^{*}, * *$, and ${ }^{* * *}$ represent significance levels at $10 \%, 5 \%$, and $1 \%$.

\begin{tabular}{|c|c|c|c|c|c|c|}
\hline & Q1 & Q2 & Q3 & Q4 & Q5 & $\mathrm{Q} 5-\mathrm{Q} 1$ \\
\hline \multicolumn{7}{|c|}{ Event-Driven } \\
\hline Average H-Bear Beta & -0.43 & -0.14 & -0.04 & 0.07 & 0.41 & 0.84 \\
\hline \multirow[t]{2}{*}{ Return } & 0.82 & 0.55 & 0.55 & 0.48 & 0.47 & $-0.35^{* * *}$ \\
\hline & $(4.51)$ & $(4.21)$ & $(4.77)$ & $(3.15)$ & $(2.25)$ & $(-2.83)$ \\
\hline \multirow[t]{2}{*}{ FH alpha } & 0.58 & 0.37 & 0.40 & 0.30 & 0.17 & $-0.41^{* * *}$ \\
\hline & $(4.95)$ & $(4.21)$ & $(5.17)$ & $(2.67)$ & $(1.78)$ & $(-3.54)$ \\
\hline \multicolumn{7}{|c|}{ Relative Value } \\
\hline Average H-Bear Beta & -0.47 & -0.13 & -0.03 & 0.06 & 0.34 & 0.80 \\
\hline \multirow[t]{2}{*}{ Return } & 0.92 & 0.63 & 0.50 & 0.35 & 0.20 & $-0.72^{* * *}$ \\
\hline & $(5.30)$ & $(6.29)$ & $(5.31)$ & $(2.72)$ & $(0.96)$ & $(-3.05)$ \\
\hline \multirow[t]{2}{*}{ FH alpha } & 0.78 & 0.55 & 0.41 & 0.24 & 0.02 & $-0.76^{* * *}$ \\
\hline & $(4.85)$ & $(6.93)$ & $(5.98)$ & $(2.39)$ & $(0.11)$ & $(-2.96)$ \\
\hline \multicolumn{7}{|c|}{ Long-Short Equity } \\
\hline Average H-Bear Beta & -0.76 & -0.23 & -0.02 & 0.18 & 0.69 & 1.44 \\
\hline \multirow[t]{2}{*}{ Return } & 0.86 & 0.64 & 0.59 & 0.56 & 0.61 & $-0.25^{*}$ \\
\hline & $(3.37)$ & $(3.57)$ & $(3.59)$ & $(2.95)$ & $(2.47)$ & $(-1.80)$ \\
\hline \multirow[t]{2}{*}{ FH alpha } & 0.46 & 0.29 & 0.25 & 0.14 & 0.12 & $-0.35^{* *}$ \\
\hline & $(2.27)$ & $(2.19)$ & $(2.43)$ & $(1.46)$ & $(0.87)$ & $(-2.17)$ \\
\hline \multicolumn{7}{|c|}{ Global Macro } \\
\hline Average H-Bear Beta & -0.62 & -0.19 & 0.00 & 0.18 & 0.65 & 1.27 \\
\hline \multirow[t]{2}{*}{ Return } & 0.92 & 0.76 & 0.49 & 0.41 & 0.22 & $-0.70^{* * *}$ \\
\hline & $(4.93)$ & $(4.96)$ & $(3.59)$ & $(3.19)$ & $(0.80)$ & $(-3.31)$ \\
\hline \multirow[t]{2}{*}{ FH alpha } & 0.79 & 0.61 & 0.35 & 0.28 & 0.02 & $-0.77^{* * *}$ \\
\hline & $(4.14)$ & $(4.11)$ & $(2.37)$ & $(2.33)$ & $(0.09)$ & $(-4.18)$ \\
\hline \multicolumn{7}{|c|}{ CTA } \\
\hline Average H-Bear Beta & -0.56 & -0.15 & 0.02 & 0.20 & 0.76 & 1.32 \\
\hline \multirow[t]{2}{*}{ Return } & 0.70 & 0.38 & 0.25 & 0.24 & 0.18 & $-0.52^{* * *}$ \\
\hline & $(4.19)$ & $(2.55)$ & $(2.26)$ & $(3.11)$ & $(1.09)$ & $(-2.98)$ \\
\hline \multirow[t]{2}{*}{ FH alpha } & 0.68 & 0.35 & 0.26 & 0.25 & 0.15 & $-0.53^{* * *}$ \\
\hline & $(4.27)$ & $(2.18)$ & $(2.43)$ & $(2.99)$ & $(0.80)$ & $(-2.81)$ \\
\hline
\end{tabular}




\begin{tabular}{|c|c|c|c|c|c|c|}
\hline \multicolumn{7}{|c|}{ Equity Market-Neutral } \\
\hline Average H-Bear Beta & -0.34 & -0.12 & -0.02 & 0.08 & 0.36 & 0.70 \\
\hline Return & 0.42 & 0.32 & 0.29 & 0.23 & 0.22 & $-0.21^{* *}$ \\
\hline & $(6.74)$ & $(6.98)$ & $(6.49)$ & $(3.21)$ & $(2.65)$ & $(-2.47)$ \\
\hline FH alpha & 0.36 & 0.26 & 0.26 & 0.17 & 0.15 & $-0.21^{* *}$ \\
\hline & $(4.74)$ & $(5.75)$ & $(5.14)$ & $(2.49)$ & $(1.99)$ & $(-2.06)$ \\
\hline \multicolumn{7}{|c|}{ Multi-Strategy } \\
\hline Average H-Bear Beta & -0.60 & -0.18 & 0.01 & 0.19 & 0.70 & 1.29 \\
\hline Return & 0.92 & 0.67 & 0.48 & 0.39 & 0.31 & $-0.61^{* * *}$ \\
\hline & $(5.26)$ & $(5.26)$ & $(5.95)$ & $(4.64)$ & $(2.50)$ & $(-2.99)$ \\
\hline FH alpha & 0.97 & 0.68 & 0.45 & 0.34 & 0.26 & $-0.71^{* * *}$ \\
\hline & $(4.35)$ & $(4.01)$ & $(4.46)$ & $(3.76)$ & $(2.13)$ & $(-2.94)$ \\
\hline \multicolumn{7}{|c|}{ Sector } \\
\hline Average H-Bear Beta & -0.53 & -0.12 & 0.10 & 0.34 & 0.94 & 1.47 \\
\hline Return & 1.10 & 0.62 & 0.76 & 0.59 & 0.51 & $-0.58^{* *}$ \\
\hline & $(2.67)$ & $(2.41)$ & $(2.07)$ & $(1.82)$ & $(1.43)$ & $(-2.01)$ \\
\hline FH alpha & 0.64 & 0.28 & 0.38 & 0.16 & 0.00 & $-0.64^{*}$ \\
\hline & $(1.96)$ & $(1.25)$ & $(1.26)$ & $(0.64)$ & $(-0.01)$ & $(-1.94)$ \\
\hline \multicolumn{7}{|c|}{ Fund of Funds } \\
\hline Average H-Bear Beta & -0.31 & -0.12 & -0.05 & 0.03 & 0.22 & 0.53 \\
\hline Return & 0.53 & 0.46 & 0.41 & 0.39 & 0.25 & $-0.28^{* * *}$ \\
\hline & $(3.96)$ & $(3.57)$ & $(3.22)$ & $(2.75)$ & $(1.71)$ & $(-3.68)$ \\
\hline FH alpha & 0.39 & 0.31 & 0.26 & 0.24 & 0.07 & $-0.32^{* * *}$ \\
\hline & $(3.09)$ & $(2.81)$ & $(2.49)$ & $(2.04)$ & $(0.67)$ & $(-3.28)$ \\
\hline
\end{tabular}


Table 11: H-Bear beta versus skills at exploiting rare disaster concern

The table investigates the difference between H-Bear beta and skills at exploiting rare disaster concern. For consistency with Gao, Gao, and Song (2018), all findings are based on the period from January 1998 to December 2011. Panel A reports the performance of decile portfolios of hedge funds sorted by the betas (or sensitivities) with respect to various versions of the RIX index over the full sample period and conditional on market crashes $($ MKT $<$ P10) versus normal times (MKT > P10). These betas are estimated by regressing hedge fund excess returns on different versions of the RIX index controlling for the market excess returns over a 24-month rolling window. At the end of each month from December 1997 to November 2011 , we sort hedge funds into deciles according to their betas on different versions of the RIX index. We rebalance the portfolios each month; thus, the portfolio returns are from January 1998 to December 2017. We measure the average equal-weighted returns for several decile portfolios and for D10-D1 portfolio. We present four sets of results. Specification (1) uses the RIX index that is made publicly available by George Gao. Specification (2) uses our replicated RIX index. Specification (3) uses a RIX index which is constructed from S\&P 500 put options. Specification (4) uses RETRIX, which is the average daily return within a month of a portfolio of S\&P 500 index put options that form RIX. Panel B reports the performance of hedge fund portfolios that are sorted on RIX betas and RETRIX betas. In Panel B.1, we first sort funds based on RETRIX betas into quintiles and within each quintile, we further sort funds into five portfolios based on RIX betas. In Panel B.2, we first sort funds based on RIX betas into quintiles and within each quintile, we sort funds into five portfolios based on RETRIX betas. We rebalance these portfolios each month and report equal-weighted as well as risk-adjusted returns. All returns and alphas are in monthly percentages. Newey and West (1987) t-statistics with lag length equal to 24 are reported in parentheses. $*, * *$, and ${ }^{* * *}$ represent significance levels at $10 \%, 5 \%$, and $1 \%$.

Panel A: Univariate portfolio-level analysis, sorted on betas with respect to various versions of the RIX index

\begin{tabular}{|c|c|c|c|c|c|c|c|c|c|c|c|}
\hline & \multicolumn{5}{|c|}{ Full sample: Jan 1998 - Dec 2010} & \multicolumn{3}{|c|}{$\mathrm{MKT}<\mathrm{P} 10$} & \multicolumn{3}{|c|}{$\mathrm{MKT}>\mathrm{P} 10$} \\
\hline & D1 & D5 & D10 & D10-D1 & FH alpha & D1 & D10 & D10-D1 & D1 & D10 & D10-D1 \\
\hline \multicolumn{12}{|c|}{ (1) Sort by fund's sensitivity to RIX index obtained from Gao et al. (2018) } \\
\hline Returns $(\%)$ & $\begin{array}{c}0.34 \\
(0.91)\end{array}$ & $\begin{array}{c}0.43 \\
(2.47)\end{array}$ & $\begin{array}{c}1.11 \\
(4.57)\end{array}$ & $\begin{array}{c}0.77^{* *} \\
(2.51)\end{array}$ & $\begin{array}{c}0.80^{* * *} \\
(3.11)\end{array}$ & $\begin{array}{l}-5.43 \\
(-4.10)\end{array}$ & $\begin{array}{l}-1.48 \\
(-2.28)\end{array}$ & $\begin{array}{l}3.94^{* *} \\
(2.42)\end{array}$ & $\begin{array}{c}1.00 \\
(3.90)\end{array}$ & $\begin{array}{c}1.41 \\
(5.78)\end{array}$ & $\begin{array}{c}0.42^{* *} \\
(1.96)\end{array}$ \\
\hline \multicolumn{12}{|c|}{ (2) Sort by fund's sensitivity to our replicated RIX index } \\
\hline Returns $(\%)$ & $\begin{array}{c}0.32 \\
(0.77)\end{array}$ & $\begin{array}{c}0.44 \\
(2.65)\end{array}$ & $\begin{array}{c}1.04 \\
(4.80)\end{array}$ & $\begin{array}{l}0.72^{* *} \\
(2.17)\end{array}$ & $\begin{array}{c}0.83^{* * *} \\
(3.09)\end{array}$ & $\begin{array}{l}-5.79 \\
(-4.50)\end{array}$ & $\begin{array}{l}-1.32 \\
(-2.25)\end{array}$ & $\begin{array}{c}4.47^{* * *} \\
(3.06)\end{array}$ & $\begin{array}{c}1.04 \\
(3.90)\end{array}$ & $\begin{array}{c}1.36 \\
(5.78)\end{array}$ & $\begin{array}{c}0.32 \\
(1.43)\end{array}$ \\
\hline \multicolumn{12}{|c|}{ (3) Sort by fund's sensitivity to our replicated RIX index that uses only options from S\&P 500} \\
\hline Returns (\%) & $\begin{array}{c}0.44 \\
(1.05)\end{array}$ & $\begin{array}{c}0.48 \\
(2.88)\end{array}$ & $\begin{array}{c}0.95 \\
(4.50)\end{array}$ & $\begin{array}{c}0.52 \\
(1.47)\end{array}$ & $\begin{array}{c}0.64^{* *} \\
(2.16)\end{array}$ & $\begin{array}{l}-5.10 \\
(-3.45)\end{array}$ & $\begin{array}{l}-1.62 \\
(-1.91)\end{array}$ & $\begin{array}{l}3.48^{*} \\
(1.67)\end{array}$ & $\begin{array}{c}1.11 \\
(3.97)\end{array}$ & $\begin{array}{c}1.28 \\
(5.91)\end{array}$ & $\begin{array}{c}0.17 \\
(0.79)\end{array}$ \\
\hline \multicolumn{12}{|c|}{ (4) Sort by fund's sensitivity to RETRIX } \\
\hline Returns $(\%)$ & $\begin{array}{c}1.10 \\
(4.07)\end{array}$ & $\begin{array}{c}0.47 \\
(2.91)\end{array}$ & $\begin{array}{c}0.35 \\
(1.15)\end{array}$ & $\begin{array}{c}-0.75^{* * *} \\
(-2.98)\end{array}$ & $\begin{array}{c}-0.83^{* * *} \\
(-2.87)\end{array}$ & $\begin{array}{l}-2.41 \\
(-9.35)\end{array}$ & $\begin{array}{l}-4.09 \\
(-7.97)\end{array}$ & $\begin{array}{c}-1.69^{* *} \\
(-2.33)\end{array}$ & $\begin{array}{c}1.51 \\
(6.04)\end{array}$ & $\begin{array}{c}0.87 \\
(4.01)\end{array}$ & $\begin{array}{c}-0.64^{* * *} \\
(-3.71)\end{array}$ \\
\hline
\end{tabular}


Panel B: Bivariate dependent portfolio-level analysis, sorted on RIX betas and RETRIX betas Panel B.1: First sort on RETRIX betas, then on RIX beta

\begin{tabular}{|c|c|c|c|c|c|c|c|}
\hline & Low $\beta^{R I X}$ & 2 & 3 & 4 & $\operatorname{High} \beta^{R I X}$ & Q5-Q1 & FH alpha \\
\hline Low $\beta^{R E T R I X}$ & 0.71 & 0.72 & 0.65 & 0.88 & 1.37 & $0.66^{* *}(2.19)$ & $0.63^{* *}(2.14)$ \\
\hline 2 & 0.46 & 0.51 & 0.51 & 0.54 & 0.77 & $0.31^{*}(1.73)$ & $0.32 * *(2.01)$ \\
\hline 3 & 0.51 & 0.47 & 0.39 & 0.50 & 0.71 & $0.20(1.46)$ & $0.21(1.58)$ \\
\hline 4 & 0.40 & 0.42 & 0.39 & 0.49 & 0.75 & $0.35^{* *}(2.06)$ & $0.41^{* * *}(2.86)$ \\
\hline High $\beta^{R E T R I X}$ & 0.23 & 0.36 & 0.27 & 0.55 & 0.75 & $0.52^{*}(1.84)$ & $0.62^{* *}(2.40)$ \\
\hline Average & 0.46 & 0.50 & 0.44 & 0.59 & 0.87 & $0.41 * *(2.13)$ & $0.44^{* * *}(2.65)$ \\
\hline
\end{tabular}

Panel B.2: First sort on RIX betas, then on RETRIX betas

\begin{tabular}{|c|c|c|c|c|c|c|c|}
\hline & Low $\beta^{R E T R I X}$ & 2 & 3 & 4 & High $\beta^{R E T R I X}$ & $\mathrm{Q} 5-\mathrm{Q} 1$ & FH alpha \\
\hline Low $\beta^{R I X}$ & 0.76 & 0.48 & 0.35 & 0.30 & 0.13 & $-0.63^{* *}(-2.00)$ & $-0.83^{* *}(-2.10)$ \\
\hline 2 & 0.65 & 0.53 & 0.46 & 0.41 & 0.40 & $-0.26^{*}(-1.70)$ & $-0.39 * *(-2.54)$ \\
\hline 3 & 0.60 & 0.45 & 0.43 & 0.40 & 0.35 & $-0.25^{* *}(-2.45)$ & $-0.33^{* * *}(-2.83)$ \\
\hline 4 & 0.75 & 0.62 & 0.50 & 0.54 & 0.44 & $-0.31^{* *}(-2.50)$ & $-0.36^{* * *}(-2.80)$ \\
\hline $\operatorname{High} \beta^{R I X}$ & 1.31 & 0.96 & 0.76 & 0.76 & 0.79 & $-0.52^{* * *}(-2.73)$ & $-0.62^{* * *}(-3.30)$ \\
\hline Average & 0.81 & 0.61 & 0.50 & 0.48 & 0.42 & $-0.39^{* * *}(-2.65)$ & $-0.51^{* * *}(-2.99)$ \\
\hline
\end{tabular}


Table 12: Robustness checks

The table reports the results from a series of robustness checks with respect to the average returns and FungHsieh alphas of hedge fund portfolios sorted by H-Bear beta. At the end of each month from December 1997 to November 2017, we sort hedge funds into quintiles according to their H-Bear beta level. Quintile 1 (5) consists of funds with the lowest (highest) H-Bear betas. We hold these quintile portfolios for one month and present the average returns and alphas for each quintile and for the Q5-Q1 portfolio. In Specification (1), average returns are weighted by the fund's AUM at the time of portfolio formation. In Specifications (2) and (3), H-Bear beta is estimated over the 12-month and 36-month rolling window, respectively. In Specifications (4) and (5), we construct the Bear portfolio by defining the bear region as states in which the market excess return is two and one standard deviations below zero, respectively. In Specification (6), we drop the short put position from the Bear portfolio and use only the long put position. In Specification (7), we set $-100 \%$ on returns of drop-out funds. All returns and alphas are in monthly percentages. Newey and West (1987) tstatistics with lag length equal to 24 are reported in parentheses. ${ }^{*}, * *$, and ${ }^{* * *}$ represent significance levels at $10 \%, 5 \%$, and $1 \%$.

\begin{tabular}{|c|c|c|c|c|c|c|}
\hline & Q1 & Q2 & Q3 & Q4 & Q5 & Q5-Q1 \\
\hline \multicolumn{7}{|c|}{ (1) Value-weighted returns } \\
\hline \multirow[t]{2}{*}{ Value-weighted returns } & 0.83 & 0.52 & 0.44 & 0.40 & 0.20 & $-0.63^{* * *}$ \\
\hline & $(6.01)$ & $(4.74)$ & $(4.38)$ & $(3.31)$ & $(1.30)$ & $(-3.42)$ \\
\hline \multirow[t]{2}{*}{ FH alpha } & 0.67 & 0.38 & 0.30 & 0.22 & -0.06 & $-0.73^{* * *}$ \\
\hline & $(4.38)$ & $(4.20)$ & $(4.03)$ & $(2.50)$ & $(-0.51)$ & $(-3.40)$ \\
\hline \multicolumn{7}{|l|}{ (2) Horizon of 12 months } \\
\hline \multirow[t]{2}{*}{ Equal-weighted returns } & 0.88 & 0.57 & 0.51 & 0.47 & 0.39 & $-0.50^{* * *}$ \\
\hline & $(5.52)$ & $(4.91)$ & $(4.26)$ & $(3.42)$ & $(1.69)$ & $(-2.75)$ \\
\hline \multirow[t]{2}{*}{ FH alpha } & 0.69 & 0.41 & 0.33 & 0.24 & 0.01 & $-0.67^{* * *}$ \\
\hline & $(4.56)$ & $(4.69)$ & $(4.18)$ & $(2.82)$ & $(0.10)$ & $(-3.36)$ \\
\hline \multicolumn{7}{|l|}{ (3) Horizon of 36 months } \\
\hline \multirow[t]{2}{*}{ Equal-weighted returns } & 0.82 & 0.56 & 0.48 & 0.44 & 0.39 & $-0.42^{* * *}$ \\
\hline & $(5.96)$ & $(5.20)$ & $(4.30)$ & $(3.66)$ & $(2.67)$ & $(-4.30)$ \\
\hline \multirow[t]{2}{*}{ FH alpha } & 0.58 & 0.39 & 0.32 & 0.26 & 0.12 & $-0.46^{* * *}$ \\
\hline & $(3.51)$ & $(3.32)$ & $(2.93)$ & $(2.61)$ & $(1.24)$ & $(-3.38)$ \\
\hline \multicolumn{7}{|l|}{ (4) $\beta_{2 \sigma}^{H-B e a r}$} \\
\hline \multirow[t]{2}{*}{ Equal-weighted returns } & 0.81 & 0.52 & 0.46 & 0.46 & 0.38 & $-0.43^{* * *}$ \\
\hline & $(4.83)$ & $(4.74)$ & $(4.00)$ & $(3.63)$ & $(2.26)$ & $(-3.16)$ \\
\hline \multirow[t]{2}{*}{ FH alpha } & 0.61 & 0.35 & 0.30 & 0.26 & 0.09 & $-0.52^{* * *}$ \\
\hline & $(3.57)$ & $(3.89)$ & $(3.28)$ & $(2.94)$ & $(0.96)$ & $(-3.18)$ \\
\hline \multicolumn{7}{|l|}{ (5) $\beta_{1 \sigma}^{H-B e a r}$} \\
\hline \multirow[t]{2}{*}{ Equal-weighted returns } & 0.84 & 0.57 & 0.47 & 0.42 & 0.33 & $-0.51^{* * *}$ \\
\hline & $(5.50)$ & $(4.97)$ & $(4.00)$ & $(3.20)$ & $(1.85)$ & $(-3.65)$ \\
\hline \multirow[t]{2}{*}{ FH alpha } & 0.69 & 0.42 & 0.31 & 0.21 & 0.00 & $-0.69^{* * *}$ \\
\hline & $(4.10)$ & $(3.88)$ & $(3.33)$ & $(2.31)$ & $(-0.05)$ & $(-4.09)$ \\
\hline \multicolumn{7}{|l|}{ (6) $\beta^{H-P U T}$} \\
\hline \multirow[t]{2}{*}{ Equal-weighted returns } & 0.80 & 0.56 & 0.48 & 0.43 & 0.35 & $-0.45^{* * *}$ \\
\hline & $(4.71)$ & $(4.61)$ & $(4.07)$ & $(3.42)$ & $(2.36)$ & $(-3.54)$ \\
\hline FH alpha & 0.60 & 0.40 & 0.32 & 0.22 & 0.07 & $-0.53^{* * *}$ \\
\hline
\end{tabular}




\begin{tabular}{lcccccc} 
& $(3.71)$ & $(3.69)$ & $(3.39)$ & $(2.61)$ & $(0.80)$ & $(-3.30)$ \\
\hline (7) Delisting returns & & & & & & \\
Equal-weighted returns & -0.18 & -0.35 & -0.46 & -0.59 & -0.99 & $-0.80^{* * *}$ \\
& $(-0.92)$ & $(-1.97)$ & $(-2.34)$ & $(-3.20)$ & $(-3.91)$ & $(-4.41)$ \\
\multirow{2}{*}{ FH alpha } & -0.37 & -0.52 & -0.63 & -0.79 & -1.30 & $-0.93^{* * *}$ \\
& $(-1.95)$ & $(-2.98)$ & $(-3.43)$ & $(-4.87)$ & $(-7.41)$ & $(-4.46)$ \\
\hline
\end{tabular}




\section{Appendix A: Definition of variables}

For each fund $i$ at the end of month $t$, we compute all variables used to predict fund returns in month $t+1$. This appendix provides detailed definition of all variables in the paper. Note that for all variables computed using the past 24 months of hedge fund return series, we require at least 18 months of non-missing returns.

\section{A.1. Time-varying fund exposures and characteristics}

$\boldsymbol{\beta}^{\boldsymbol{H}-\boldsymbol{B E A R}}$ or H-Bear beta: is the coefficient $\beta_{i, t}^{H-B E A R}$ obtained by regressing monthly hedge fund excess returns on the market excess returns and the Bear portfolio excess returns: $r_{i, t}=\alpha_{i, t}+\beta_{i, t} \times M K T_{t}+$ $\beta_{i, t}^{H-B E A R} \times r_{\text {Bear }, t}+\epsilon_{i, t}$ over a 24 -month rolling-window period. Details of the Bear portfolio construction is provided in Section 2.

$\boldsymbol{\beta}^{M K T}$ : is the coefficient $\beta_{i, t}^{M K T}$ from the regression of monthly hedge fund excess returns on the market excess returns: $r_{i, t}=\alpha_{i, t}+\beta_{i, t}^{M K T} \times M K T_{t}+\epsilon_{i, t}$ over the past 24 months.

$\boldsymbol{\beta}^{\boldsymbol{\Delta V O L}}, \boldsymbol{\beta}^{\boldsymbol{\Delta S K E W}}$, and $\boldsymbol{\beta}^{\boldsymbol{\Delta K U R T}}$ (Agarwal, Bakshi, and Huij, 2010): are exposures to higher risk-neutral moments obtained by regressing monthly hedge fund excess returns on the market excess returns and $\triangle V O L_{t}$, $\triangle S K E W_{t}$, and $\triangle K U R T_{t}$ (monthly relative changes in the market volatility, skewness, and kurtosis respectively) over a 24-month rolling-window period: $r_{i, t}=\alpha_{i, t}+\beta_{i, t}^{M K T} \times M K T_{t}+\beta_{i, t}^{\triangle V L} \times \Delta V O L_{t}+$ $\beta_{i, t}^{\Delta K E W} \times \Delta S K E W_{t}+\beta_{i, t}^{\Delta K U R T} \times \Delta K U R T_{t}+\epsilon_{i, t}$. Market volatility, skewness, and kurtosis are the Bakshi, Kapadia, and Madan (2003) model-free estimate of risk-neutral higher moments of market log return spanning the period up to option maturity day. They are extracted from S\&P 500 index options using trapezoidal approximation and are linearly interpolated to have the measures with constant 30-day maturity.

TailRisk (Agarwal, Ruenzi, and Weigert, 2017): is defined as the lower tail dependence of hedge fund returns and the market returns over the past 24 months $\left(\right.$ TailSens $\left._{i, t}\right)$, multiplied by the ratio of the absolute value of their respective expected shortfalls over the same period with the cutoff of $\mathrm{q}=5 \%$. TailSens $s_{i, t}$ of fund $i$ takes the value of zero, 0.5 , or 1 if none, one, or both of the fund's two worst return realizations occur at the same time of the market's two worst monthly returns over the past 24 months.

$\beta^{U N C}$ (Bali, Brown, and Caglayan, 2014): is hedge fund exposure to macroeconomic uncertainty, $\beta_{i, t}^{U N C}$, from the regression of monthly hedge fund excess returns on the economic uncertainty index: $r_{i, t}=\alpha_{i, t}+$ $\beta_{i, t}^{U N C} \times U N C_{t}+\epsilon_{i, t}$ over the past 24 months. The monthly economic uncertainty index is provided on Bali's personal website.

$\boldsymbol{\beta}^{\boldsymbol{R I} \boldsymbol{X}}$ (Gao, Gao, and Song, 2018): is interpreted as skills at exploiting rare disaster concern, which is the coefficient, $\beta_{i, t}^{R I X}$, from the regression of monthly hedge fund excess returns on the market excess returns and the rare disaster concern index (RIX) over the past 24 months: $r_{i, t}=\alpha_{i, t}+\beta_{i, t}^{M K T} \times M K T_{t}+$ $\beta_{i, t}^{R I X} \times R I X_{t}+\epsilon_{i, t}$. Data for RIX is obtained from Gao's website and covers the period over 1996-2011.

$\boldsymbol{\beta}^{\boldsymbol{R E T R I X}}$ : is the coefficient on RETRIX obtained by regressing monthly hedge fund excess returns on the market excess returns and the Investable RIX factor (RETRIX) over the rolling 24-month window period: $r_{i, t}=\alpha_{i, t}+\beta_{i, t}^{M K T} \times M K T_{t}+\beta_{i, t}^{R E T R I X} \times R E T R I X_{t}+\epsilon_{i, t}$. Monthly Investable RIX factor is computed as follows. We modify the formula for RIX slightly to allow the use of available option quotes.

$$
\begin{aligned}
R I X=V^{-}-I V^{-}= & \frac{2 e^{r \tau}}{\tau} \int_{K<S_{t}} \frac{\ln \left(S_{t} / K\right)}{K^{2}} P\left(S_{t} ; K, T\right) d K \\
& \approx \frac{2 e^{r \tau}}{\tau} \sum_{i=1}^{n_{P}} \frac{\ln \left(S_{t} / K_{i}^{P}\right)}{\left(K_{i}^{P}\right)^{2}} P\left(S_{t} ; K_{i}^{P}, T\right) \Delta K_{i}^{P}
\end{aligned}
$$


where $\tau \equiv T-t$ is the time to maturity, $r$ is the risk-free rate, $S_{t}$ is the spot price, $n_{P}$ is the number of OTM puts with available price data, $i$ indexes the OTM puts, $K_{i}^{P}$ is the strike of $i$ th OTM put option when the strikes are ordered in decreasing order, and $P\left(S_{t} ; K_{i}^{P}, T\right)$ is price of the put with strike $K_{i}^{P}$ maturing at $\mathrm{T}$. $\Delta K_{1}^{P}=S-K_{1}^{P}$ and $\Delta K_{i}^{P}=K_{i-1}^{P}-K_{i}^{P}$ for $2 \leq i \leq n^{P}$. For constructing RETRIX, each day, we follow the formula to form the option position using all valid OTM put options on the S\&P 500 index that expire on the third Friday of the next calendar month. The option position is hold for one day to calculate the return. We then take the average of the daily option position returns within a month to calculate monthly RETRIX.

R2 (Titman and Tiu, 2011): is the $\mathrm{R}^{2}$ measure of a fund from the regression of monthly hedge fund excess returns on the Fung and Hsieh (2004) seven factors over the past 24 months.

SDI (Sun, Wang, and Zheng, 2012): is strategy distinctiveness for a fund calculated as one minus the correlation between the fund returns and the average returns of funds with the same investment style based on the past 24 months.

Downside Return (Sun, Wang, and Zheng, 2018): is computed as the time-series average of fund $i$ returns during months in which aggregate hedge funds returns are below the median level over the past 24 months.

Age: is the age of hedge fund $i$ since its inception (measured in years)

Size: is computed as natural log of asset under management (in $\$$ million) of hedge fund $i$ in month $t$.

Ret VOL, SKEW, KURT: are respectively the standard deviation, skewness, and kurtosis of fund $i$ monthly returns over the past 24 months.

Past return (12M): is the cumulative return of fund $i$ over the past 12 months ending in month $t$.

\section{A.2. Time-invariant fund characteristics}

Min Investment: is computed as the natural $\log$ of $(1+$ minimum investment amount).

Management Fee: is the annual management fee (in percentage) for hedge fund $i$.

Incentive Fee: is the annual incentive fee (in percentage) for hedge fund $i$.

Lock Up: is the minimum length of time (measured in months) that investors are required to keep their money invested in fund $i$.

Redemption: is the length of advanced notice that hedge fund $i$ requires from investors who wish to redeem their shares.

Leverage: is an indicator variable that takes the value of one if hedge fund $i$ uses leverage.

Hurdle: is an indicator variable that takes the value of one if hedge fund $i$ uses a hurdle rate.

HWM: is an indicator variable that takes the value of one if hedge fund $i$ use high watermark.

Offshore: is an indicator variable that takes the value of one if hedge fund $i$ is based in offshore location outside of the USA.

\section{A.3. Hedge fund risk factors}

PTFSBD: Monthly return on trend-following risk factor in bonds

PTFSFX: Monthly return on trend-following risk factor in currencies.

PTFSCOM: Monthly return on trend-following risk factor in commodities.

S\&P: The S\&P 500 index monthly total return.

SCMLC: The size spread factor, computed as the difference between the Russell 2000 index monthly return and the S\&P 500 monthly return.

BD10RET: The bond market factor, computed as the monthly change in the 10-year treasury maturity yield.

BAAMTSY: The credit spread factor, computed as the monthly change in the Moody's Baa yield less 10year treasury constant maturity yield. 